Atmos. Chem. Phys., 18, 10575-10591, 2018

https://doi.org/10.5194/acp-18-10575-2018

(c) Author(s) 2018. This work is distributed under

the Creative Commons Attribution 4.0 License.

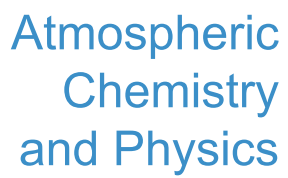

(c) (P)

\title{
Combining airborne in situ and ground-based lidar measurements for attribution of aerosol layers
}

\author{
Anna Nikandrova ${ }^{1}$, Ksenia Tabakova $^{1}$, Antti Manninen $^{1}$, Riikka Väänänen ${ }^{1}$, Tuukka Petäjä ${ }^{1}$, Markku Kulmala $^{1}$, \\ Veli-Matti Kerminen ${ }^{1}$, and Ewan O'Connor ${ }^{2}$ \\ ${ }^{1}$ Institute for Atmospheric and Earth System Research/Physics, Faculty of Science, University of Helsinki, Helsinki, Finland \\ ${ }^{2}$ Finnish Meteorological Institute, Helsinki, Finland
}

Correspondence: Anna Nikandrova (anna.nikandrova@helsinki.fi)

Received: 22 November 2017 - Discussion started: 25 January 2018

Revised: 2 July 2018 - Accepted: 5 July 2018 - Published: 25 July 2018

\begin{abstract}
Understanding the distribution of aerosol layers is important for determining long-range transport and aerosol radiative forcing. In this study we combine airborne in situ measurements of aerosol with data obtained by a groundbased high spectral resolution lidar (HSRL) and radiosonde profiles to investigate the temporal and vertical variability of aerosol properties in the lower troposphere. The HSRL was deployed in Hyytiälä, southern Finland, from January to September 2014 as a part of the U.S. DOE ARM (Atmospheric Radiation Measurement) mobile facility during the BAECC (Biogenic Aerosols - Effects on Cloud and Climate) Campaign. Two flight campaigns took place in April and August 2014 with instruments measuring the aerosol size distribution from $10 \mathrm{~nm}$ to $5 \mu \mathrm{m}$ at altitudes up to $3800 \mathrm{~m}$. Two case studies with several aerosol layers present were selected from the flight campaigns for further investigation: one clearsky and one partly cloudy case. During the clear-sky case, turbulent mixing ensured small temporal and spatial variability in the measured aerosol size distribution in the boundary layer, whereas mixing was not as homogeneous in the boundary layer during the partly cloudy case. The elevated layers exhibited larger temporal and spatial variability in aerosol size distribution, indicating a lack of mixing. New particle formation was observed in the boundary layer during the clear-sky case, and nucleation mode particles were also seen in the elevated layers that were not mixing with the boundary layer. Interpreting local measurements of elevated layers in terms of long-range transport can be achieved using back trajectories from Lagrangian models, but care should be taken in selecting appropriate arrival heights, since the modelled and observed layer heights did not always coincide. We con-
\end{abstract}

clude that higher confidence in attributing elevated aerosol layers to their air mass origin is attained when back trajectories are combined with lidar and radiosonde profiles.

\section{Introduction}

Aerosols are tiny particles suspended in the atmosphere that severely affect human health (e.g. Tie et al., 2009; Apte et al., 2015; Pope III et al., 2015) and climate. Most of the particles have a direct cooling effect on climate by scattering solar radiation (e.g. McCormick and Ludwig, 1967; Sundström et al., 2015, Lacagnina et al., 2017) and an indirect one by changing cloud properties (e.g. Haywood and Boucher, 2000; Ten Hoeve and Augustine, 2016; Saponaro et al., 2017), yet some of the particles have a warming effect by absorbing solar radiation (Yu et al., 2006). The average lifetime of aerosol particles in the boundary layer (BL) varies from several hours to 2 weeks (Seinfield and Pandis, 2006) and they can be transported far from their source of origin. However, they are not distributed uniformly, with aerosol concentrations and properties varying significantly in space and time. Thus, it is challenging to implement aerosol schemes in global climate models (e.g. Myhre et al., 2013; Zhang et al., 2016; Glassmeier et al., 2017) and the impact of aerosol remains one of the largest sources of uncertainty in climate predictions (IPCC, 2013).

Most aerosol particles are emitted from the surface (Kaufman et al., 2002) or are formed from their precursor gases either close to the surface or higher up in the free troposphere (e.g. Kulmala et al., 2004, 2007, 2013; Dunne et al., 2016). 
Turbulent mixing distributes aerosol uniformly throughout the well-mixed BL, but stable stratification elsewhere in the atmosphere usually inhibits any further mixing. Hence, layers can form once the source of turbulent mixing is removed, one example being the formation of residual layers after sunset (Stull, 2012). Here, we define elevated layers as those existing above the well-mixed daytime BL. This can include residual layers if the boundary-layer depth is suppressed on subsequent days. Deep convection (Andreae et al., 2001; Wang et al., 2016) and midlatitude cyclones (Sinclair et al., 2010) can transport aerosol vertically throughout the troposphere, and, once in the free troposphere, baroclinic systems can advect aerosol over long distances (Donnell et al., 2001). Wet deposition and evaporation to the gas phase are the main removal mechanisms for aerosol above the BL, although it is also possible for elevated aerosol layers to be mixed back into the BL after some time being aloft (Clarke et al., 2001).

The vertical distribution of aerosol particles is important for determining the direct and indirect aerosol radiative forcing (Haywood and Ramaswamy, 1998). Lidar measurements are able to track the evolution of aerosol layers with a high resolution in space and time (e.g. Wandinger et al., 2002; Groß et al., 2011; Burton et al., 2012; Pappalardo et al., 2014; Baars et al., 2016). Reid et al. (2017) looked at the monthly variability of backscatter profiles from a high spectral resolution lidar (HSRL) located in Hunstsville, Alabama, U.S. during summer and reported that aerosol backscatter was highest below $1.5 \mathrm{~km}$ and decreased rapidly with increasing height until $3.5 \mathrm{~km}$. They also occasionally observed different layering structures in the free troposphere, which was in general a clear region with low aerosol concentration. During the Two-Column Aerosol Project (TCAP, Berg et al., 2016) in which the atmospheric column was studied, both at the coast of North America and several hundred kilometres away in the Atlantic Ocean using second-generation HSRL-2 (Müller et al., 2014), elevated aerosol layers were observed on four out of six clear-sky research flights with contributions of up to $60 \%$ of the total column aerosol optical depth. Fast et al. (2016) found that some of these elevated aerosol layers were likely lifted from the BL as a result of strong synopticscale convergence. Smoke events may be responsible for elevated layers with significant contributions to the total column aerosol optical depth (O'Neill et al., 2008).

An airborne HSRL-2 was used to constrain the vertical distribution of aerosol microphysical properties observed in California and Texas (Sawamura et al., 2017). Microphysical properties retrieved from HSRL-2 showed good agreement with in situ measurements; however, backscatter and extinction coefficients calculated from corresponding in situ measurements were consistently underestimated, which was attributed to the undersampling of coarse mode particles by in situ measurements. Combined data from diverse measurement campaigns over the Pacific show that the free troposphere was dominated by aerosols formed near cloud edges and in convective regions, as well as particles transported from continents (Clarke and Kapustin, 2002).

Detailed information on aerosol size distributions and microphysical properties can be obtained from in situ airborne measurements. However, compared to the quantity of aerosol measurements at the surface, there have been relatively few flight campaigns investigating elevated aerosol layers, especially at low aerosol load conditions. Boy et al. (2004), O'Dowd et al. (2009), and Schobesberger et al. (2013) conducted airborne measurements over a boreal forest, primarily interested in new particle formation (NPF). New particles were observed throughout the BL in all three studies, but Schobesberger et al. (2013) reported much lower particle concentrations outside the BL. This suggests that in the boreal forest large-scale NPF events are typically confined to the BL, similar to results found in other environments (e.g. Crumeyrolle et al., 2010; Berland et al., 2017).

In this study, our aim was to investigate aerosol layers in a rural environment, their origin, and how they change over time. We were particularly interested in how the aerosol size distribution varied both within and between layers. This information could be used to determine whether there was mixing within and between layers and whether there had been any recent contact with the surface. For this purpose, a comprehensive set of ground-based remote sensing observations together with both airborne and ground-based aerosol measurements were collected during the Biogenic Aerosols - Effects on Cloud and Climate (BAECC) campaign in Hyytiälä, Finland during 2014 (Petäjä et al., 2016). We used HSRL measurements from the surface and scanning mobility particle sizer (SMPS) and optical particle sizer (OPS) measurements on board an aircraft, described in Sect. 2, to analyse aerosol layers in two case studies, described in Sect. 3. The first case represents typical clear-sky weather conditions during spring at the station with a clean air mass arriving from the north. This is an ideal case because the development of the BL and elevated aerosol layers could be monitored for several days without interruption. The second case is more complicated, with partly cloudy and unstable atmospheric conditions. Back-trajectory analysis was conducted for both case studies to examine whether these analyses produced similar layer structures to those observed and how closely the diagnosed layer altitudes corresponded to those observed by the HSRL.

\section{Experimental set-up}

The SMEAR II (Station for Measuring Forest EcosystemAtmosphere Relations II; see Hari and Kulmala, 2005) measurement station located in Hyytiälä, southern Finland $\left(61^{\circ} 51^{\prime} \mathrm{N}, 24^{\circ} 17^{\prime} \mathrm{E}, 181 \mathrm{~m}\right.$ a.s.l. $)$ is a rural background station with no major anthropogenic emission sources located nearby. During the BAECC campaign, the US Department of Energy Atmospheric Radiation Measurement (ARM) pro- 
gramme deployed the HSRL in Hyytiälä from January to September 2014 as a part of the ARM mobile facility (AMF). Vaisala RS92 radiosondes (RS) were launched 4 times a day during the campaign (nominally at 00Z, 06Z, 12Z, and 18Z).

\subsection{Instrumentation}

\subsubsection{High spectral resolution lidar}

AMF HSRL (Shipley et al., 1983; Grund and Eloranta, 1991; She et al., 1992; Eloranta, 2015) is an autonomous lidar system designed to retrieve vertical profiles of the backscatter coefficient, extinction coefficient, and depolarisation. The system uses a frequency-doubled Nd:YAG laser emitting pulses at a wavelength of $532 \mathrm{~nm}$ and a repetition rate of $4 \mathrm{kHz}$, together with an afocal telescope with a diameter of $40 \mathrm{~cm}$ acting as both transmitter and receiver. The telescope has a field of view of $45 \mu \mathrm{rad}$, which limits the impact of multiple scattering, and the large expansion of the outgoing beam means that the system is eye-safe, permitting the flight campaign to operate in the immediate vicinity of the instrument. Continuous profiles can be detected from around $50 \mathrm{~m}$ up to $30 \mathrm{~km}$ in altitude. The emitted laser light is circular polarised. The detection chain utilises photon counting to record the atmospheric return in three channels: combined, molecular, and cross-polarisation, at $0.5 \mathrm{~s}$ and $7.5 \mathrm{~m}$ resolution. The combined channel contains backscattering from both particulates and molecules, whereas the molecular channel includes an iodine absorption filter (Eloranta and Razenkov, 2006) in the path to record molecular scattering only, and the cross-polarisation channel measures the degree of circular polarisation relative to the combined channel. The polarisation split occurs before the Rayleigh-Mie split. Full details on the instrument set-up are available in the ARM HSRL instrument handbook (Goldsmith, 2016). The profile of attenuation is determined from the known profile of molecular scattering, enabling direct retrievals of extinction, backscatter, and particulate depolarisation up to an optical depth of 4 . To reduce noise, the raw data were averaged to $5 \mathrm{~s}$ and $30 \mathrm{~m}$ before deriving the backscatter, extinction, and circular depolarisation profiles.

\subsubsection{Airborne aerosol measurements}

In situ airborne data in the lower atmosphere were obtained with a Cessna 172 light aircraft and modified for the research flights by replacing the back seats with a rack for the instruments (see Schobesberger et al., 2013; Väänänen et al., 2016). The sample air was collected from under one wing, away from the engine exhaust, and transferred inside the cabin via a stainless steel tube (inner diameter $22 \mathrm{~mm}$, length $4.2 \mathrm{~m}$ ). The inlet line was a downscaled version of one used by the University of Hawaii DC-8 with the aerodynamic particle cut-off diameter of $5.0 \mu \mathrm{m}$ (McNaughton et al., 2007), and the flow of the main inlet line was kept at $50 \mathrm{~L} \mathrm{~min}^{-1}$.
The aerosol and gas instruments were situated in a rack inside the cabin. The total aerosol number concentration was measured with an ultrafine condensation particle counter (uCPC, model 3776, TSI Inc.), whereas a scanning mobility particle sizer (SMPS) was used to determine the particle number size distribution in the diameter range of $10-230 \mathrm{~nm}$ with a temporal resolution of $2 \mathrm{~min}$. The SMPS comprised a short Hauke-type differential mobility analyser (DMA) with closed-loop sheath air, and a TSI 3010 CPC as a particle counter. SMPS data were inverted using the method introduced by Collins et al. (2002). An optical particle sizer (OPS, model 3330, TSI Inc.) measured the particle number size distribution in the diameter range of $300-5000 \mathrm{~nm}$ with a temporal resolution of $10 \mathrm{~s}$. All particle instruments were calibrated in the laboratory prior to the campaign, with errors in CPC total concentrations and SMPS particle counts below $10 \%$. All aerosol data were corrected to the standard temperature and pressure $(100 \mathrm{kPa}$ and $273.15 \mathrm{~K})$.

One intensive flight campaign took place in spring and another one in autumn 2014. A typical measurement flight took $2-3 \mathrm{~h}$ and consisted of numerous legs of about $40 \mathrm{~km}$ in length flown above the SMEAR II measurement station at Hyytiälä. The Cessna 172 air speed was low, around $35 \mathrm{~m} \mathrm{~s}^{-1}$ $\left(130 \mathrm{~km} \mathrm{~h}^{-1}\right)$, enabling a relatively high vertical resolution ( $300 \mathrm{~m}$ for SMPS and $80 \mathrm{~m}$ for OPS). The maximum flight ceiling was $3800 \mathrm{~m}$ a.s.1. A typical flight plan consisted of a climb up to the free troposphere and constant altitude legs at different altitudes. A typical climb or descent rate during the flights was $2.5 \mathrm{~m} \mathrm{~s}^{-1}$. A GPS instrument was used to record the flight track.

\subsection{Methods}

We investigated aerosol size distributions in the BL and elevated atmospheric layers that were identified by utilising HSRL backscatter and depolarisation fields. A wavelet decomposition was used to determine layer boundaries, similar to the approach used in STRAT (Structure of the Atmosphere; Morille et al., 2007). Since our work is based on individual case studies, suitable coefficients for the layerdetection algorithm were decided based on a visual inspection. On a clear-sky day, most of the aerosol load in the boreal forest area is concentrated in the BL. Therefore, the BL was easily distinguishable by the high peaks in backscatter coefficient as a consequence of strong aerosol scattering. Layers classified with the HSRL were confirmed with the RS measurements, where edges of layers could be seen in changes of specific and relative humidity profiles. The closest in-time RS measurements were used if the times of the Cessna flight and the RS launch did not match. We only considered layers below $3800 \mathrm{~m}$ in this study, as it was the maximum altitude of the Cessna.

The SMPS and OPS measurements were combined in order to obtain a size distribution ranging from $10 \mathrm{~nm}$ to $5 \mu \mathrm{m}$. Because the SMPS measures the dry size (particles are dried 
(a)

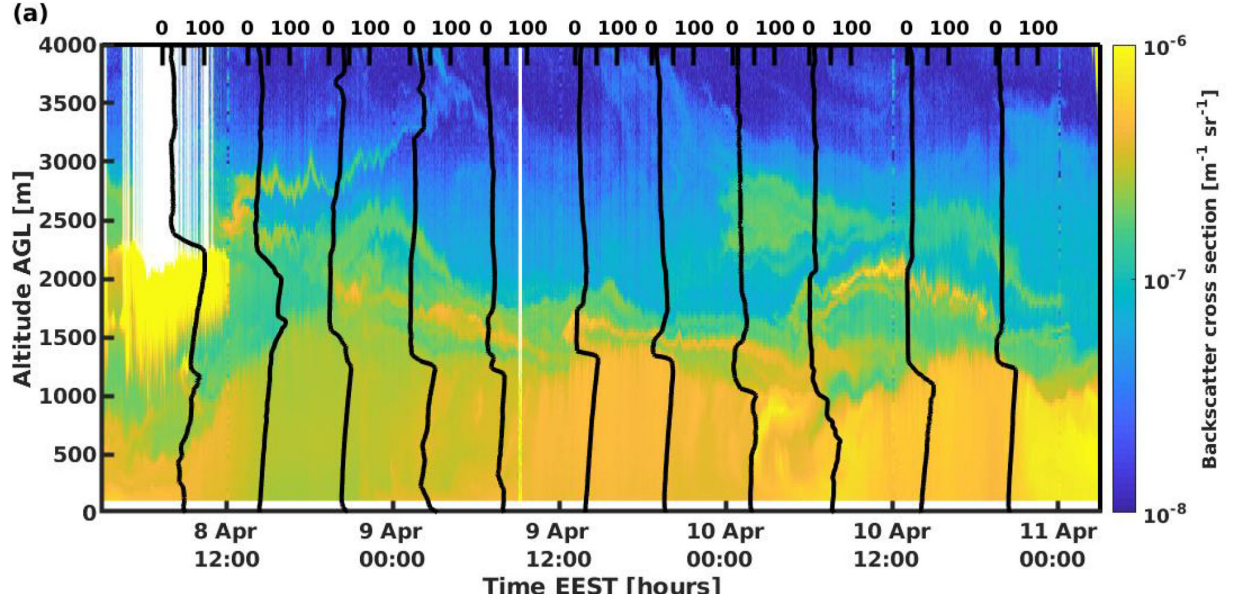

(b)

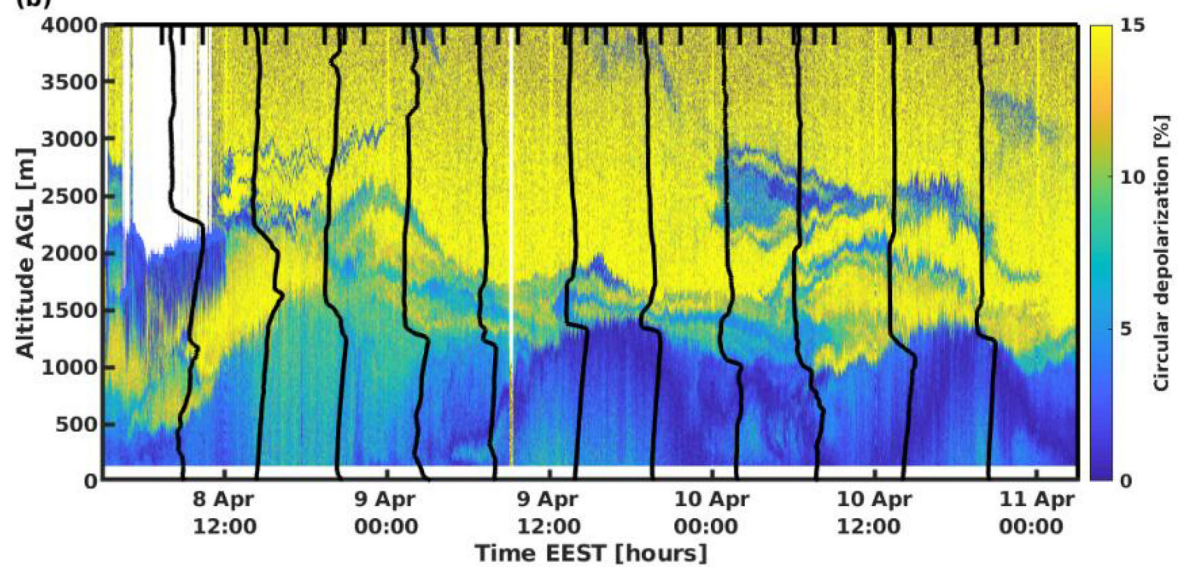

(c)

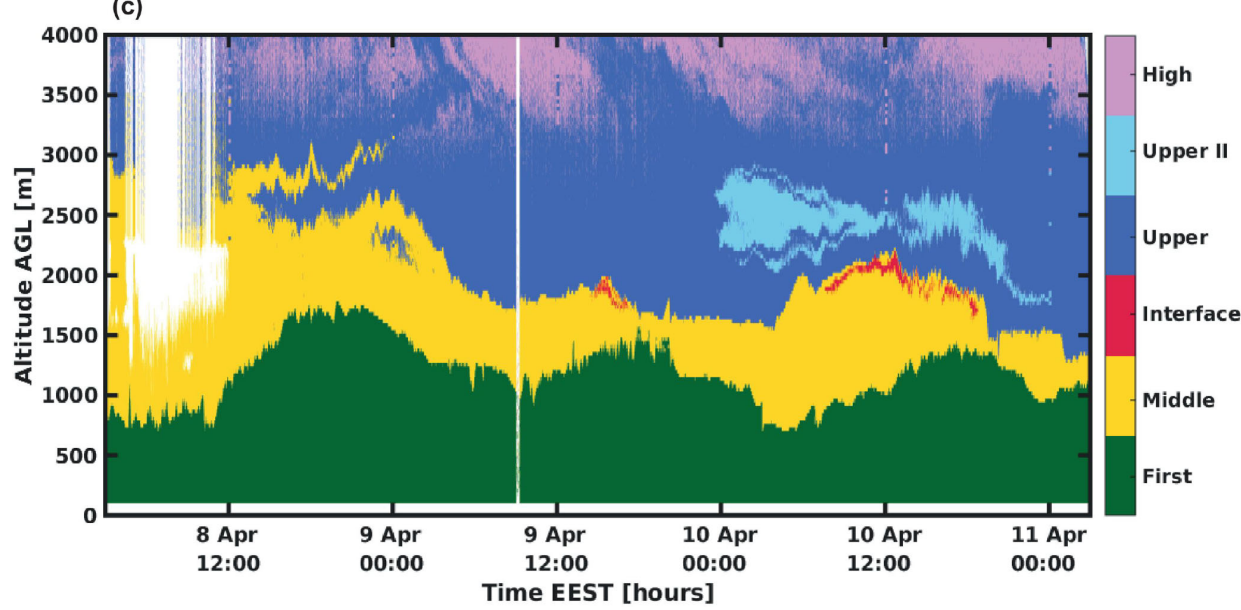

Figure 1. Case I: (a) HSRL backscatter coefficient and (b) HSRL circular depolarisation over Hyytiälä, Finland during 8-10 April 2014, with 6-hourly radiosonde relative humidity profiles superimposed in black. Larger values of the backscatter cross section indicate higher aerosol number concentration or larger particles; larger depolarisation values suggest less spherical particles. (c) Layers diagnosed from gradients in backscatter or depolarisation, with the first layer (green) comprising both boundary layer and residual layer. White pixels indicate no valid measurement due to the presence of cloud and subsequent attenuation (before midday on 12 April) or due to the calibration period (around 10 EEST on 9 April). 
prior to entry), and OPS measures the ambient size (at an ambient relative humidity), the measured SMPS size distributions were modified to represent the growth expected at the ambient relative humidity by using a growth factor (GF) calculated for a boreal forest environment using measurements from Hyytiälä station by Laakso et al. (2004). The GF was implemented as a function of $\mathrm{RH}$, measured by the radiosonde, and was between about 1.2 and 1.4 at $90 \% \mathrm{RH}$ for the range of the observed particle sizes (20-230 nm). During most of the considered flights the $\mathrm{RH}$ was not higher than $50 \%$, and the GF was lower than 1.1. The ambient size distributions were then grouped by similarities in the size distribution and by taking into account the layer boundaries found in the HSRL data. Only data in the vicinity of Hyytiälä were used, with data obtained within $50 \mathrm{~km}$ of the airport excluded from any analysis.

Here, we will use the term nucleation mode for particles with diameters smaller than $25 \mathrm{~nm}$, Aitken mode for particles ranging from 25 to $100 \mathrm{~nm}$, accumulation mode for particles from $100 \mathrm{~nm}$ to $1 \mu \mathrm{m}$, and supermicron particles for particles from 1 to $5 \mu \mathrm{m}$. All times are given in Eastern European Summer Time $(\mathrm{UTC}+3)$.

To investigate the spatial variability of arriving air masses in space and height, we calculated $96 \mathrm{~h}$ back trajectories for every $50 \mathrm{~m}$ for the altitudes from 500 to $3500 \mathrm{~m}$ a.g.l. using the HYSPLIT model (Stein et al., 2015). The National Center for Environmental Prediction (NCEP) Global Data Assimilation System (GDAS) data set with one-degree resolution was used for the meteorological input to the model.

\section{Results and discussion}

Two case studies were selected, both with air masses coming from the north but with different atmospheric conditions. The first case study (Case I) consists of 3 sequential clear-sky days with NPF events detected at the ground level each day. The second case study (Case II) consists of a single day with low-level clouds present and no NPF taking place.

\subsection{Case I: typical clear-sky situation during 8-10 April}

Figure 1a displays the HSRL backscatter coefficient from 50 to $4000 \mathrm{~m}$ for Case I, with higher values of backscatter cross section indicating either higher particle concentrations or larger particle sizes. The figure illustrates how the BL and other layers were developing, evolving, and mixing during this period. The amount of lidar depolarisation, shown in Fig. 1b, depends on the particle shape and also clearly illustrates the evolving atmospheric structures and their boundaries. Sharp changes in relative humidity $(\mathrm{RH})$ seen in the RS profiles also agree with the layer determination obtained from the HSRL backscatter cross section and depolarisation. However, not all HSRL-determined layers exhibit a corre- sponding change in RH (for example, on 8 April at 14:00 at $2800 \mathrm{~m})$.

The simplified layer structure shown in Fig. 1c was obtained from the HSRL backscatter and depolarisation fields. Four layers were identified, denoted as the first, middle, upper, and high layers. The first layer includes both the BL and the residual layer, as it was not possible to separate them with our simple algorithm. Figure 1c demonstrates that, in April, the first layer in Hyytiälä can reach up to $1500 \mathrm{~m}$ during the day and is usually shallow at night (lower than $1000 \mathrm{~m}$ ). There were several elevated layers on 8 April, one of which disappeared during the day, with no major new layers appearing on 9 April. On 10 April, a new layer exhibiting high backscattering and low depolarisation developed at around $2500 \mathrm{~m}$. Additionally, a narrow band with a high backscatter cross section (relative to surroundings) on 9 and 10 April was initially classified as a separate layer and then termed an interface zone after closer inspection. The interface zone was a shallow zone situated at the boundary between two more substantial layers and was characterised by depolarisation values that are different from the surroundings and large backscatter values in this zone. No corresponding thin layer was detected in the humidity profiles, whether from the radiosonde or aircraft. During these 3 days, six flights were made with the Cessna (one morning flight and one afternoon flight each day). Four flights were selected for analysis; these are described in more detail below and summarised in Table 1. In Fig. 2, for each flight, a panel comprising three plots displays

1. radiosonde profiles of $\mathrm{RH}$ and specific humidity mixing ratio,

2. time-height HSRL backscatter cross section with the Cessna flight altitude superimposed, and

3. mean and \pm 1 standard deviation of the aerosol size distribution obtained from SMPS and OPS measurements within each layer.

\subsubsection{Case I: flight descriptions}

Four layers in the HSRL backscatter coefficient were recognised during the Cessna flight between 16:00 and 17:30 EEST on 8 April 2014, as shown in Fig. 2b. The RH and specific humidity mixing ratio from the RS (Fig. 2a), launched $2 \mathrm{~h}$ before the flight at 14:22 EEST, also shows several distinct layers in the profile which correspond well with those identified by the HSRL. The profile of the specific humidity mixing ratio indicated that the BL layer was well mixed, whereas the corresponding values changed through the other layers.

The size distributions displayed four distinct distribution shapes corresponding to the four layers observed by the HSRL (Fig. 2c). The BL was characterised by high aerosol concentrations of up to $6000 \mathrm{~cm}^{-3}$ in the Aitken mode due to the NPF event that took place earlier in the afternoon. The 

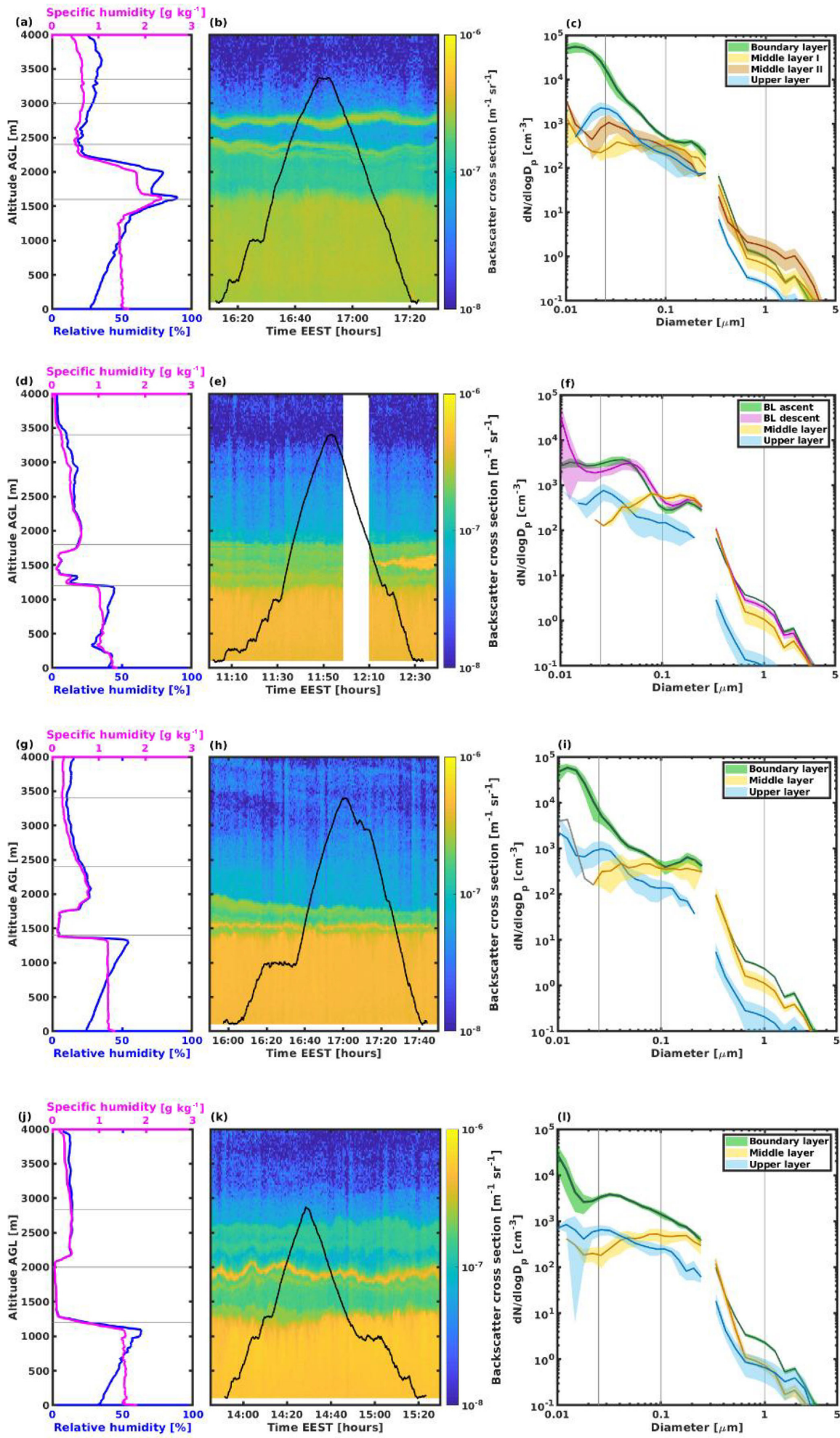

Figure 2. Four panels for each flight during Case I: (a-c) 8 April, (d-f) morning flight on 9 April, (g-i) afternoon flight on 9 April, (jl) 10 April. Left panels show relative and specific humidity profiles measured by the radiosonde launched closest in time to the flight. Centre panels display HSRL backscatter coefficient, with Cessna flight altitude superimposed in black. Right panels present layer-averaged aerosol size distributions from combined SMPS and OPS measurements for diagnosed layers. Mean and 1 standard deviation are shown for each layer. Grey lines show limits of the aerosol modes: nucleation, Aitken, accumulation, and coarse. 
Table 1. Case study I: flight times, diagnosed layer parameters (boundary, middle and upper layers height and depth in metres) and new particle formation (NPF) start time.

\begin{tabular}{lrrrrrrr}
\hline Date & $\begin{array}{r}\text { Time } \\
\text { EEST }\end{array}$ & $\begin{array}{r}\text { BL } \\
\text { height }\end{array}$ & $\begin{array}{r}\text { Middle layer } \\
\text { height }\end{array}$ & $\begin{array}{r}\text { Middle layer } \\
\text { depth }\end{array}$ & $\begin{array}{r}\text { Upper layer } \\
\text { height }\end{array}$ & $\begin{array}{r}\text { Upper layer } \\
\text { depth }\end{array}$ & $\begin{array}{r}\text { NPF start time } \\
\text { in Hyytiälä }\end{array}$ \\
\hline 8 April & $16: 00-17: 30$ & 1600 & $1600-2400$ & 800 & $3100-3350$ & 250 & $10: 00$ \\
& & & $2400-3100$ & 700 & & & \\
9 April 1 & $11: 00-12: 30$ & $1000 / 1200$ & $1000-1500$ & 500 & $1500-3400$ & 1900 & $11: 30$ \\
9 April 2 & $16: 00-17: 40$ & 1400 & $1400-1800$ & 400 & $1800-3400$ & 1600 & $11: 30$ \\
10 April & $13: 45-15: 30$ & 1200 & $1200-2000$ & 800 & $2000-2800$ & 800 & $09: 30$ \\
\hline
\end{tabular}

lowest concentrations of Aitken mode particles were found in the first middle layer. The second middle layer had a similar size distribution shape for particles smaller than $100 \mathrm{~nm}$ but at higher concentrations and displayed the highest concentrations of supermicron particles, even higher than in the BL. The second middle layer also exhibited much more depolarisation than the other layers (Fig. 1b), together implying long-range transport of large non-spherical particles. Nucleation mode particle concentrations were higher than Aitken mode particle concentrations in both middle layers, whereas no particles smaller than $15 \mathrm{~nm}$ were detected in the upper layer. However, the upper layer had much higher concentrations of $20-40 \mathrm{~nm}$ particles than the other elevated layers.

The first Cessna flight on 9 April took place from 11:00 to 12:30 EEST (Fig. 2d-f). Three distinct layers were observed below $3500 \mathrm{~m}$, also visible in the RS humidity profiles. The middle layer was significantly drier than both the BL and the layer above. The mean aerosol size distribution in the BL is shown separately for the ascent and descent profiles (Fig. 2f), illustrating that there was a notable increase in the nucleation mode particle concentration during the descent. The middle layer was characterised by a low Aitken mode concentration and high accumulation and supermicron mode concentrations. The upper layer displayed a similar aerosol size distribution shape to the one in the BL but with considerably smaller concentrations.

The same three layers were seen during the second Cessna flight, which took place from 16:00 to 17:40 EEST (Fig. 2gi). The humidity profiles were also similar to the morning flight. The impact of the NPF and subsequent growth is clearly seen in the BL aerosol size distribution (Fig. 2i), with Aitken mode concentrations reaching $5000 \mathrm{~cm}^{-3}$, much higher than observed during the morning. The size distributions in the middle and upper layers were similar to the morning flight except for the nucleation mode. No particles smaller than $15 \mathrm{~nm}$ were detected in the upper and middle layers during the morning flight, but these were observed in the afternoon flight, providing evidence for NPF in elevated layers. Due to the relatively low resolution of SMPS measurements ( $2 \mathrm{~min}$ and $300 \mathrm{~m}$ ), nucleation mode particles were detected only at one height in the middle layer. Therefore, there were not enough measurements to calculate mean size distribution and standard deviation, and these measurements are shown in grey (Fig. 2i). Nevertheless, we believe that the measured nucleation mode particles in this layer are not an artefact, because increased concentration of particles was also observed by the uCPC at the same heights as the SMPS (not shown).

On 10 April the Cessna flew in the afternoon from 13:45 to 15:30 EEST (Fig. 2j-1). Three distinct layers are visible in the humidity profiles, but the HSRL data suggest four, subdividing the upper layer into two. In addition, the HSRL observed a very thin layer, which we will discuss separately in Sect. 3.1.5. The aerosol size distributions in each layer are similar to those in the previous day. The upper layer also exhibited higher concentrations in the supermicron mode.

\subsubsection{Case I: size distribution variability within layers}

We also investigated the variability in the aerosol size distribution within each layer, which is illustrated in Fig. 2c, f, i, 1 with the standard deviation above and below the mean size distribution for each layer. The smallest variability was usually observed in the BL, indicating that this layer was well mixed vertically and horizontally with similar aerosol concentrations at all heights. Large variability was sometimes seen in the ultrafine range in the $\mathrm{BL}$, which was attributed to NPF events (Dal Maso et al., 2005; Kulmala et al., 2013). NPF events in the boreal forest around the station took place every day during the case study period. NPF is usually initiated soon after the clean air masses enters the boreal forest zone (Tunved et al., 2006). For the morning flight on 9 April, the variability for all size ranges was small during the ascent but increased in the ultrafine range during the descent (Fig. 2f); the ascent and descent profiles were separated by an hour and the NPF event began after the Cessna left the BL while ascending. During the afternoon flight on the same day $4 \mathrm{~h}$ later, when the NPF event had finished, the BL appeared homogeneous again with a small variability for almost all sizes except for particles between 20 and $30 \mathrm{~nm}$ (Fig. 2i). On 10 April, the variability in the BL nucleation mode was also quite high, a result of the still ongoing NPF event (Fig. 21).

In contrast, a larger variability in the size distribution was seen for the elevated layers, where there is much less turbulent mixing, with more variation seen at almost all 

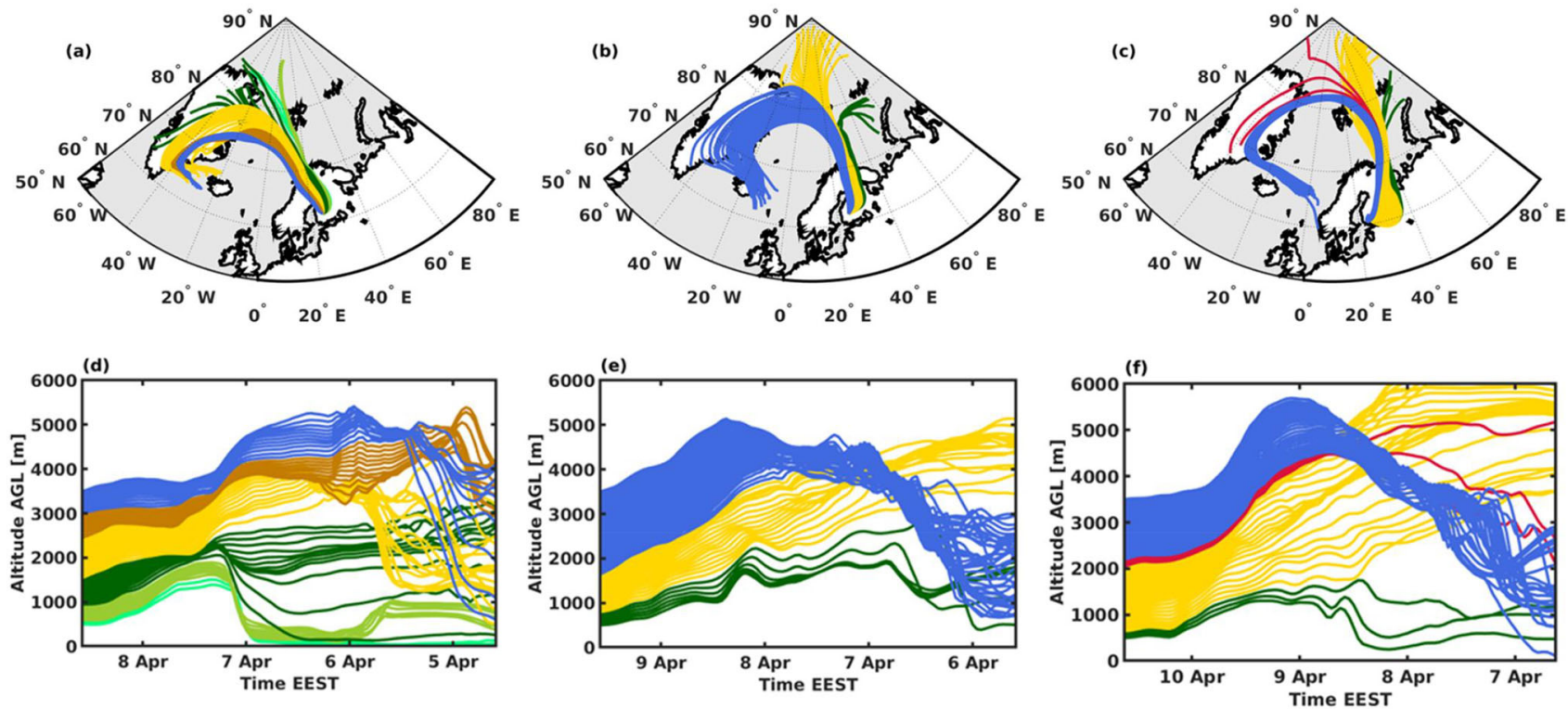

Figure 3. HYSPLIT $96 \mathrm{~h}$ backward trajectories arriving at Hyytiälä calculated every $50 \mathrm{~m}$ in altitude from 500 to $3500 \mathrm{~m}$. Panels (a-c) show spatial coverage and panels (d-f) display the trajectory altitude over time. Trajectories with similar origin/altitude properties are combined into layers with the same colours as the layers identified with HSRL in Fig. 1c. Panels (a) and (d) show trajectories arriving on 8 April at 17:00, panels (b) and (e) on 9 April at 17:00 and panels (c) and (f) on 10 April at 14.00.
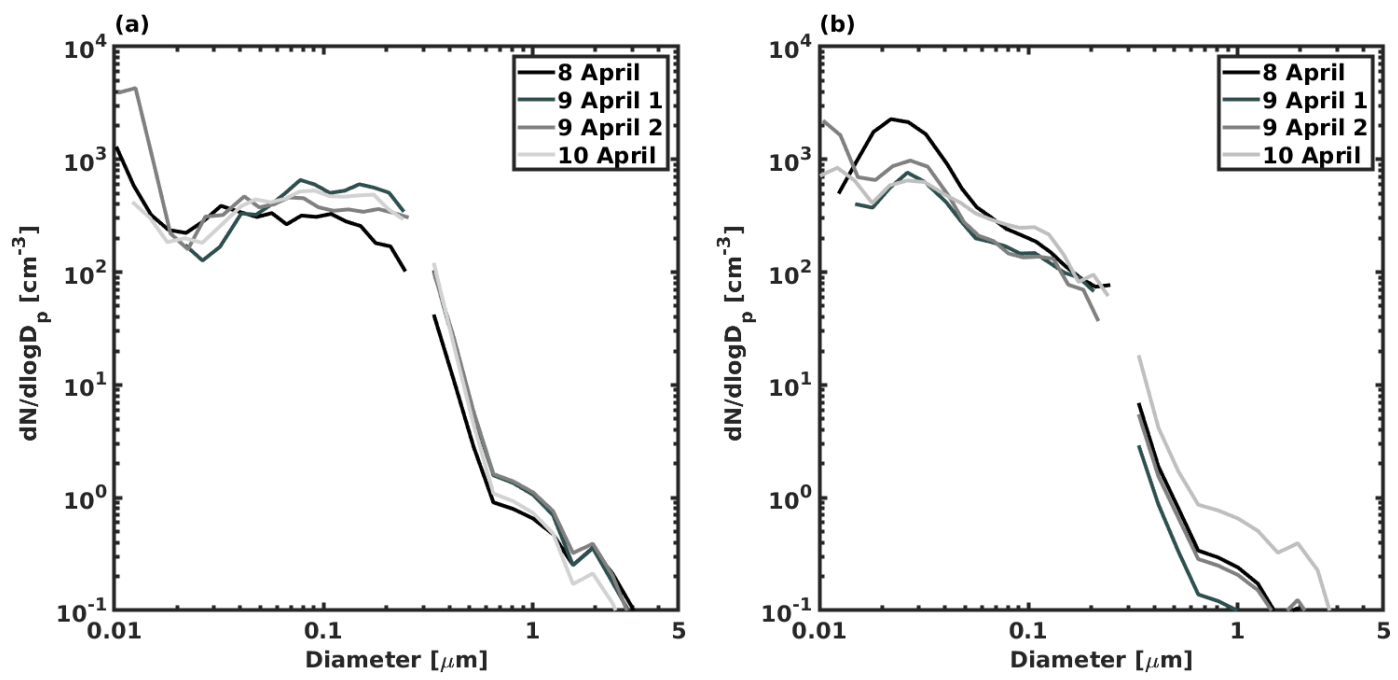

Figure 4. Evolution of the mean aerosol size distribution in Case study I for (a) middle and (b) upper layers. Minimal change in the size distribution during 3 consecutive days implies that the middle layer did not mix with surrounding air. Upper layer does show changes over time, suggesting some entrainment.

size ranges. The middle layer exhibited a similar variability across all 3 days, whereas the upper layer showed some changes from day to day, probably due to changes in the depth of the layer. On 8 April, the upper layer appeared to be less than $500 \mathrm{~m}$ deep but was as much as $1900 \mathrm{~m}$ deep on 9 April. It is difficult to ascertain the variability in the nucleation mode size range $(<25 \mathrm{~nm})$ for the elevated layers, as there may have been no particles or too few for the instrument to obtain reliable counts.

\subsubsection{Case I: back-trajectory analysis}

Figure 3 shows the origin of the air masses arriving at SMEAR II each day for Case I, based on HYSPLIT back trajectories. The trajectories were separated into layers based on similarities in origin and the tracks in altitude over which they were advected. On 8 April most trajectories were from the north-west after spending some time over Greenland and the North Sea. Trajectories at the lowest altitudes, associated 
with the $\mathrm{BL}$, came more from the Arctic Ocean (two lighter green shades in Fig. 3a, b). On 9 and 10 April, BL trajectories still arrived from the Arctic Ocean, but from further east.

The middle layer (yellow colour in Fig. 3) showed the largest variation in air mass origin, with trajectories arriving from Greenland on 8 April having been at lower altitudes of around $1000 \mathrm{~m} 2$ days before their arrival, and then from the Arctic Ocean on 9 and 10 April having descended from higher altitudes of 4000 to $6000 \mathrm{~m}$. The descent from higher altitudes implies drier air once it descends. This change in the middle layer was seen in the RS profiles in Fig. 1a: the relatively moist middle layer on 8 April gave way to a relatively dry layer on 9 April.

The air mass origin for the upper layer (blue colour in Fig. 3) remained the same throughout Case I, arriving via Greenland having previously been over the North Atlantic. All the trajectories had previously been at altitudes of $1000 \mathrm{~m}$, then were elevated to altitudes above $3000 \mathrm{~m}$ for several days before reaching the station. This layer was always dominated by Aitken mode particles (see aerosol size distributions in Fig. 2); the aerosol particles did not have the right conditions to grow larger than the Aitken mode because the upper layer was relatively dry and had probably not been in contact with the ground-based emissions of aerosol precursor compounds for at least several days. Figure $3 \mathrm{c}$ and $\mathrm{f}$ also indicate that the interface layer (in red) on 10 April was at the altitude where trajectories arrived from two distinct spatial origins.

Overall, the air masses separated using backward trajectories corresponded very well with the layers recognised using the HSRL. The altitudes did not match perfectly, especially with regard to the thickness of the elevated layers and the height of the BL. On 9 and 10 April, for example, the trajectory BL height was lower than the BL seen from the HSRL and, consequently, the trajectory analysis suggested a thicker middle layer. BL height diagnosed from trajectory analyses was $50-800 \mathrm{~m}$ lower than that observed, whereas for elevated layers, the layer boundary heights were better represented, with departures typically less than $200 \mathrm{~m}$. These larger height differences for layers associated with the BL top are attributed to the difficulties that meteorological models have in representing the BL (e.g. Holtslag et al., 2013), which are then propagated through to the trajectories.

\subsubsection{Case I: evolution of the elevated layers}

The evolution of the mean aerosol size distribution for the middle layer during Case I is shown in Fig. 4a. The aerosol particle concentrations remained similar across all the size ranges, except for sizes within the nucleation mode, and an increase in accumulation mode particle number concentrations was observed between 8 and 9 April. The change in accumulation mode is attributed to the change in air mass during this time. The lack of variation for most sizes indicates that there was essentially no mixing between the mid-
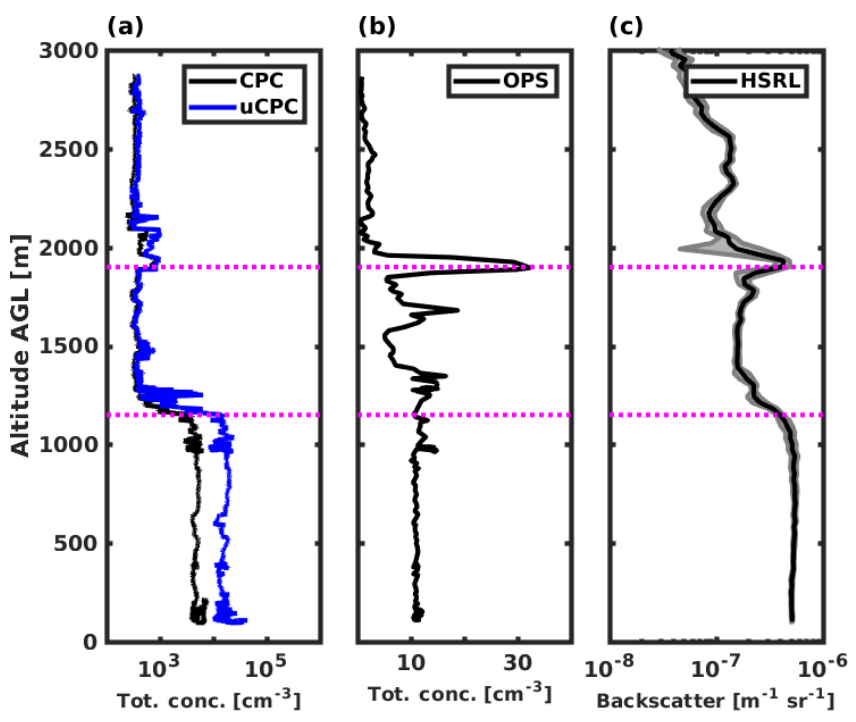

Figure 5. Vertical profiles of (a) total particle concentration measured by uCPC and CPC, (b) total particle concentration measured by OPS, (c) HSRL backscatter coefficient averaged over the time taken for the Cessna ascent over Hyytiälä, Finland, on 10 April 2014. All panels show a presence of a thin layer at $1900 \mathrm{~m}$ (dashed magenta line) with OPS indicating enhanced contribution of larger $(0.3-5 \mu \mathrm{m})$ particles.

dle layer and the surrounding layers during this period. The large increase in nucleation mode particle concentrations for the afternoon flight of 9 April demonstrated that new particles could be formed in this layer.

In contrast, the upper layer exhibited a large degree of variation in the aerosol size distributions across the 3 days of Case I (Fig. 4b). For particles smaller than $300 \mathrm{~nm}$, the shape of the size distribution and concentrations changed from day to day. For particles larger than $300 \mathrm{~nm}$, while the shape of the distribution remained similar, the number concentration varied across all 3 days. This layer might have been influenced by mixing with air above the maximum altitude of Cessna measurements.

\subsubsection{Case I: interface layer}

We separately examined a thin $150 \mathrm{~m}$ boundary between the middle and upper layers on 10 April. This layer was characterised by strong scattering seen in the HSRL backscatter coefficient at around $1900 \mathrm{~m}$ (Fig. 2k) and it was located in the area of RH change from 5 to $15 \%$. Backward trajectories showed that this layer was a section where air masses of two different origins and heights intersected. The panels of Fig. 5 demonstrate the total particle concentration measured by the $\mathrm{CPC}$ and $\mathrm{uCPC}$ during the ascent, the OPS data with a $10 \mathrm{~s}$ time resolution, as it was impossible to trace this interface layer only with the 2 min time resolution data of the SMPS. The HSRL backscatter cross section data were averaged over the time of the Cessna ascent. Peaks on all three panels oc- 

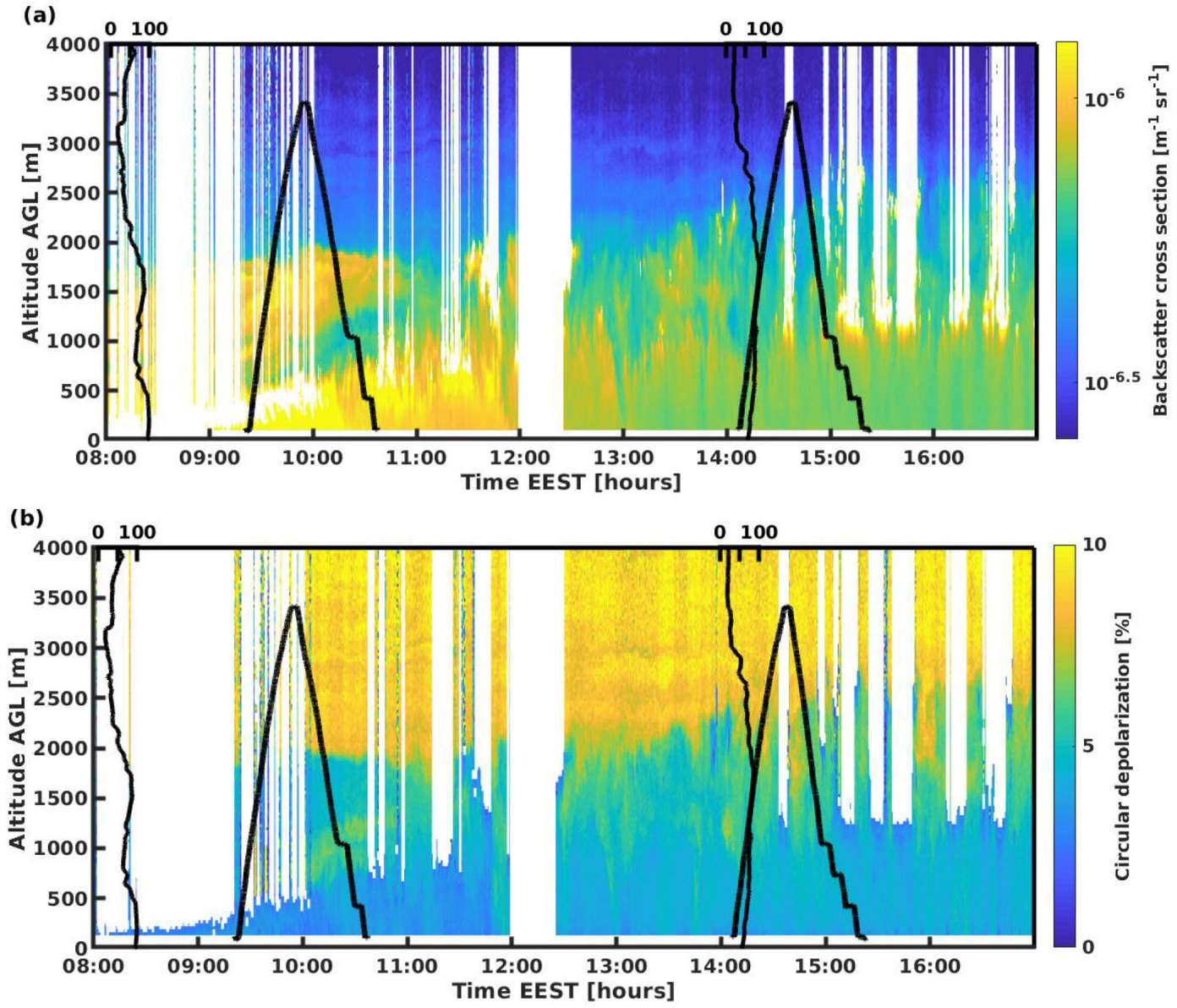

Figure 6. Case II: (a) HSRL backscatter coefficient and (b) HSRL circular depolarisation over Hyytiälä, Finland on 22 August 2014 , with 6-hourly radiosonde relative humidity profiles, and the two Cessna flight altitude tracks superimposed in black. White pixels indicate no valid measurement due to the presence of cloud and subsequent attenuation above or maintenance periods.

curred at the same height of $1900 \mathrm{~m}$. On the first panel, showing the measurements of the CPC and $\mathrm{UCPC}$, there was a peak in the total particle concentration, whereas concentrations of particles smaller than $10 \mathrm{~nm}$, measured by the uCPC, did not change. A very high peak of 33 particles $\mathrm{cm}^{-3}$ in comparison to the rest of the profile was seen on the total concentration of particles of $0.3 \mu \mathrm{m}$ to $5 \mu \mathrm{m}$, measured by the OPS. When the size distribution was examined, it was found that the contribution to this peak came from particles in the diameter range of $300-500 \mathrm{~nm}$. This thin layer could be either a result of limited small-scale mixing between two layers that were probably stable or the result of large-scale transport of smoke or dust; however, we suspect that this is a response of aerosol growing rapidly as it moves from very dry air to much moister conditions, especially since the low HSRL circular depolarisation values suggest that particles in this thin layer were relatively spherical. More data and further analyses are needed to understand the processes that lead to higher values of a backscatter cross section in these interface areas.

\subsection{Case II: cloudy on 22 August}

Figure 6 shows HSRL backscatter coefficient and circular depolarisation ratio from 50 to $4000 \mathrm{~m}$ for Case II. Backscatter values were, in general, higher than for Case I even though the aerosol number concentrations were similar for both cases, attributed to the much higher relative humidity in Case II and resulting in significant aerosol hygroscopic growth. Fog was present from 06:00 to 09:30, severely attenuating the signal. As the fog lifted, the lidar was able to occasionally penetrate and detect the deep residual layer above that extended to $1850 \mathrm{~m}$ in altitude. The residual layer showed low depolarisation and high backscatter values characteristic of a humid BL, in contrast to the layers above $1850 \mathrm{~m}$. The BL started to mix into the residual layer during the morning at around 1100 and continued to deepen to at least $2000 \mathrm{~m}$ by mid-afternoon. The cloud radar showed that occasional cumulus clouds were formed from $1000 \mathrm{~m}$ in altitude and were able to grow to at least $3000 \mathrm{~m}$ in altitude by late afternoon. Ground-based measurements from 

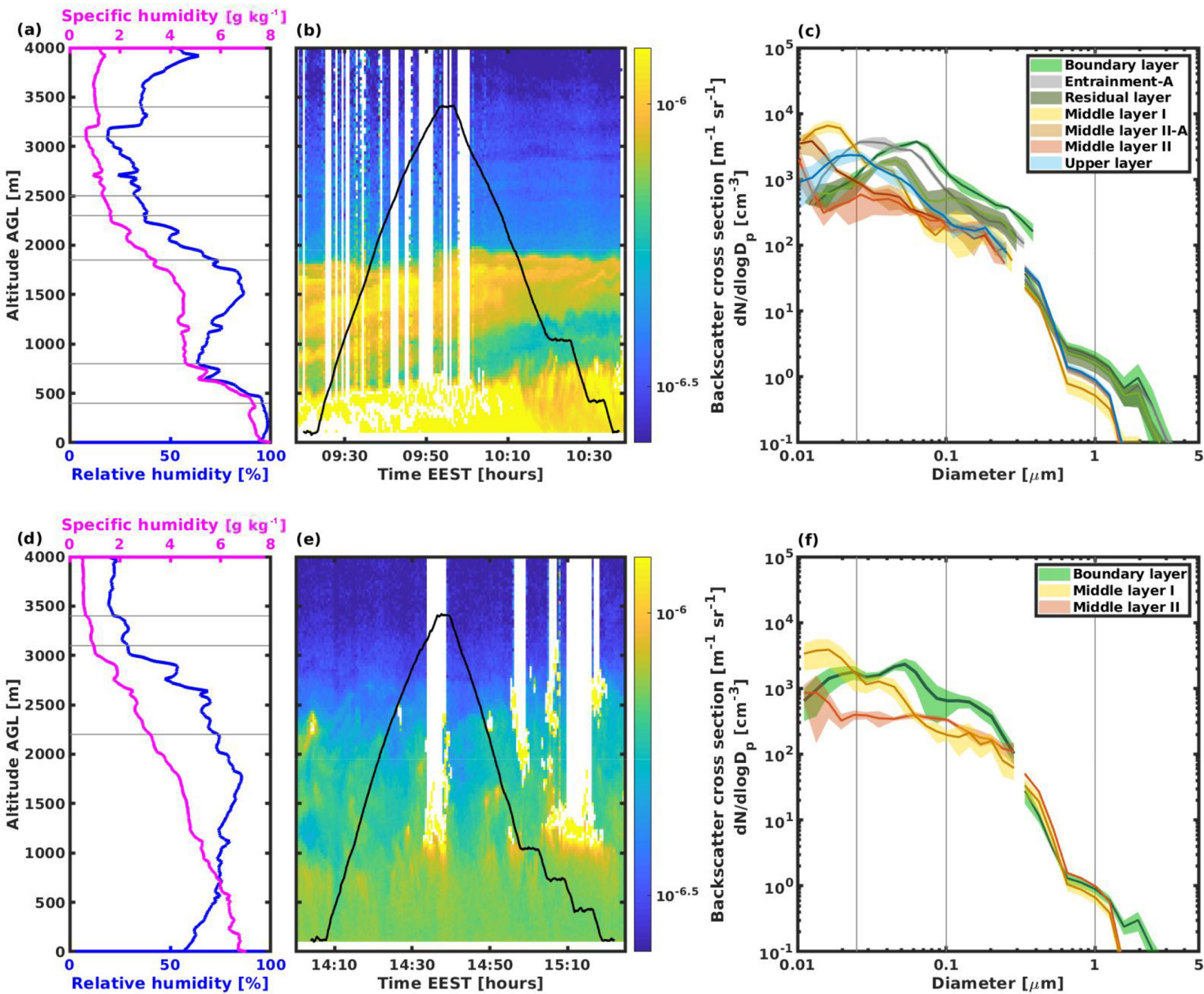

Figure 7. Same as Fig. 2 except for Case II with (a-c) morning flight (d-f) afternoon flight.

the SMEAR II station indicated that there was no NPF event at the surface during this case study.

Two flights were made with the Cessna during this day, one morning flight and one afternoon flight, and these are described in more detail below. Figure 7 was generated with similar panels to Case I for each flight.

\subsubsection{Case II: flight description}

The first Cessna flight on 22 August took place from 09:30 to 10:30. Even though the HSRL signal was often fully attenuated by fog or low cloud, the height of the growing BL and the presence of the residual layer are clear in Fig. 7a-c. Both layers were also obvious in the radiosonde profile, launched $1 \mathrm{~h}$ before the Cessna flight commenced. The BL RH was close to $100 \%$; hence there was fog with a constant specific humidity mixing ratio of about $7 \mathrm{~g} \mathrm{~kg}^{-1}$. Between this layer and the residual layer was an entrainment zone in which the specific humidity mixing ratio was decreasing rapidly with height. The residual layer above the entrainment zone also exhibited a relatively constant specific humidity mixing ratio of about $4.5 \mathrm{~g} \mathrm{~kg}^{-1}$, from 700 to $1850 \mathrm{~m}$. Above $1850 \mathrm{~m}$, the specific humidity mixing ratio decreased to about $1 \mathrm{~g} \mathrm{~kg}^{-1}$; the profile indicated several additional layers, but these were difficult to distinguish in the HSRL backscatter coefficient and circular depolarisation ratio.

Together with the airborne in situ measurements, seven layers were diagnosed (Fig. 7c), classified as belonging to three main groups: first (green), middle (yellow), and upper (blue) layers. The first group comprised the BL, residual layer, and the entrainment zone. As a group, these layers displayed low concentrations of nucleation mode particles but much higher concentrations in all other modes, relative to the layers above. The three layers in this group exhibited differences mostly in the Aitken mode: the BL and entrainment zone exhibited a peak at different sizes in the Aitken mode, whereas the residual layer exhibited a Hoppel minimum for sizes in the $0.08-0.1 \mu \mathrm{m}$ region characteristic of cloud processing (Hoppel et al., 1990). The middle group was also separated into three layers, displaying differences in the nucleation and Aitken mode number concentrations. These lay- 

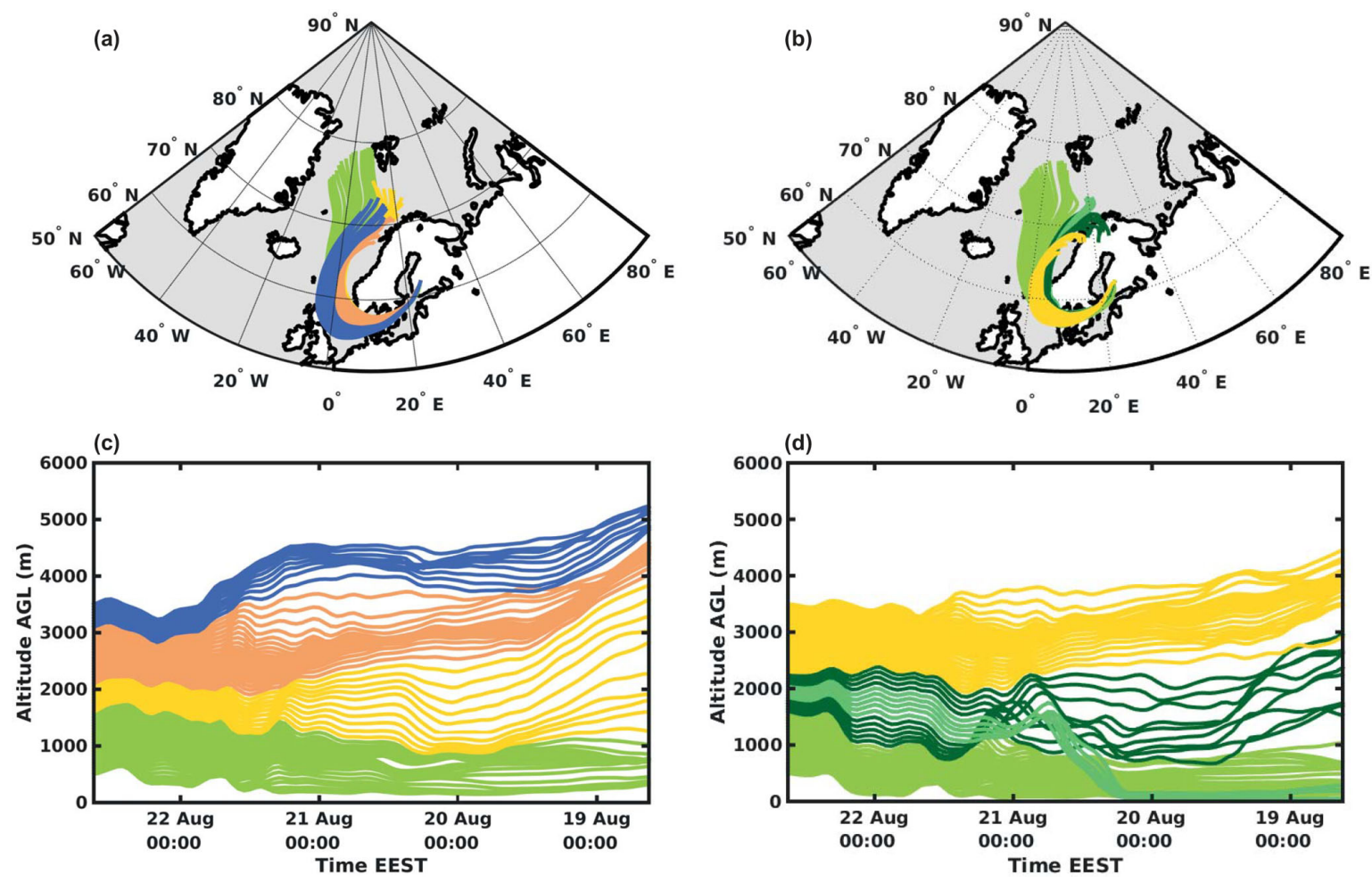

Figure 8. Same as Fig. 3 except for Case II with (a) and (c) showing trajectories arriving at 10:00 and panels (b) and (d) at 14:00.
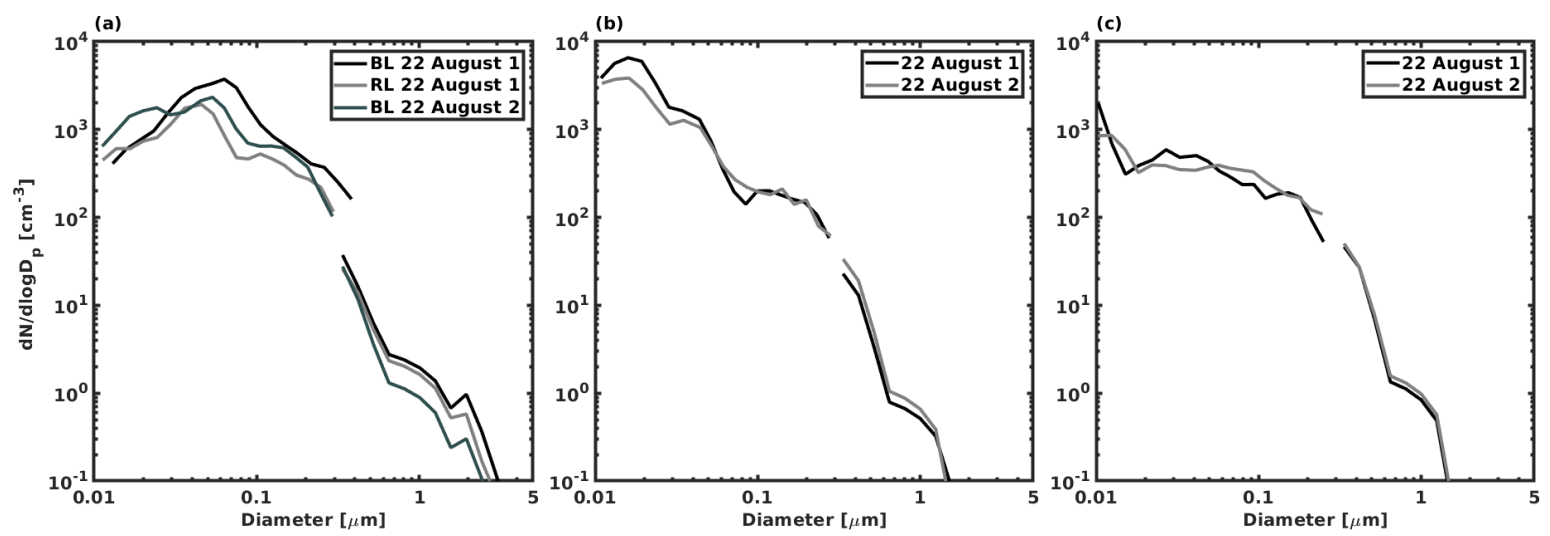

Figure 9. Evolution of the mean aerosol size distribution in Case II for (a) boundary layer, (b) first middle layer, and (c) second middle layer.

ers corresponded well with the humidity structure seen in the radiosonde profile. The aerosol size distribution in the upper layer was similar to the one in the lowest layer in the middle group, except for lower concentrations below $30 \mathrm{~nm}$.

The second Cessna flight on 22 August took place from 14:00 to $15: 30$ (Fig. 7d-f). Several cumulus clouds were present during the flight and can be seen in the HSRL backscatter coefficient (Fig. 7e). The BL had now grown to consume the residual layer from the previous day, but the radiosonde profile suggests that the BL was not as well mixed as one would expect for a classical $\mathrm{BL}$ - the profile of specific humidity mixing ratio was not constant and $\mathrm{RH}$ did not always increase with height. The BL was well mixed up to $600 \mathrm{~m}$ and became progressively less well mixed above this, with convectively buoyant air parcels reaching up to $2500 \mathrm{~m}$. The radiosonde thermodynamic profile suggested that deep convection to $4 \mathrm{~km}$ or so was possible and did indeed occur later on in the day. Three layers were identified in the airborne data: the BL and two middle layers. The shape of the aerosol size distribution in the BL was similar to the residual layer of the earlier flight, also displaying a Hoppel minimum $(0.09 \mu \mathrm{m})$. The middle layers were separable with respect to Aitken mode particle concentrations and could also be diagnosed from the radiosonde profiles. They corresponded with 
the middle layers seen during the descent of the morning flight. The upper layer of the morning flight was not detected during this flight due to the limitations of the Cessna flight ceiling. Interestingly, nucleation mode particles were detected in all layers during both flights of Case II.

\subsubsection{Case II: size distribution variability within layers}

The elevated layers showed the same variability in the aerosol size distribution as was observed in Case I for particles smaller than $300 \mathrm{~nm}$ but smaller variability in the accumulation and coarse modes. The BL exhibited larger variability in the aerosol size distribution than was seen for the clearsky case (Case I), even during the afternoon flight (Fig. 7f). The radiosonde profiles show that the BL was not as well mixed as in Case I, as the specific humidity mixing ratio was not constant with height (Fig. 7d), in strong contrast to the BL profiles seen in Fig. 3. The residual layer exhibited a profile of specific humidity mixing ratio that was relatively constant (Fig. 7a), presumably a result of a well-mixed BL on the previous day, but this layer was no longer turbulent and showed some variability in the size distribution. The BL was clearly convective, but the mixing was not homogeneous, indicated by the presence of cumulus clouds that were forming as a result of more organised updraughts.

\subsubsection{Case II: back-trajectory analysis}

Figure 8 shows the origin of the air masses arriving at SMEAR II each day for Case II, based on HYSPLIT back trajectories. As for Fig. 3, the trajectories were separated into layers based on similarities in origin and the altitude tracks over which they were advected. Similar to Case I, the air mass origins were from the north, but now travelled over the relatively warm Baltic sea before arriving at the station, where air in the BL could pick up moisture and become more humid. There was little change in altitude over the 4 days for the majority of the back trajectories; however, by midafternoon, there were some trajectories inserted into the upper portion of the BL over Hyytiälä that had been close to the surface prior to their ascent over the Norwegian mountains between 06:00 and 18:00 EEST on 20 August (Fig. 8d; light-green layer).

For this case, it would have been much harder to identify any layers based on back-trajectory analysis alone, since there was not much change in altitude over time or in spatial origin. The set of trajectories that had been elevated from the surface (Fig. 8d; light-green layer) would have been mixed into the BL by the time they reached the station.

\subsubsection{Case II: evolution of the layers}

The BL aerosol size distribution measured during the afternoon flight resembled the distribution seen in the residual layer during the morning flight (Fig. 9a), with a Hoppel minimum suggesting that cloud processing is still visible for sizes around $0.07 \mu \mathrm{m}$. The afternoon BL displayed higher concentrations of nucleation mode particles than both the residual layer and morning BL but decreased concentrations of particles above $500 \mathrm{~nm}$. This may due to dilution as the growing BL entrains air from above with lower concentrations in this size range. Both middle layers showed little change in the aerosol size distribution between the morning and afternoon flights, except for small differences in the nucleation mode for the first middle layer (Fig. 9b). This may be a result of occasional localised cloud-driven entrainment when cumulus clouds begun to extend into the first middle layer during the second flight. This was also indicated in the HSRL measurements (Figs. 6 and 7e) as the BL top was more diffuse (Fig. 7c) and quite variable even on short timescales, changing by as much as $1 \mathrm{~km}$ in $10 \mathrm{~min}$. The presence of cumulus clouds suggests that the BL top was spatially heterogeneous.

\section{Summary and conclusions}

We present an analysis of aerosol layers over a relatively clean background measurement station based on a combined data set comprising ground-based remote sensing observations, radiosonde profiles and airborne in situ measurements. Two case studies were chosen: a typical clear-sky situation lasting for 3 consecutive days and a partly cloudy day. Several elevated aerosol layers were detected in both cases. For the clear-sky case, the highest aerosol number concentrations were observed in the BL, for all modes. The radiosonde profiles indicated a classic well-mixed profile within the BL, which was also apparent in the small temporal variability in the measured aerosol size distributions. Outside the well-mixed BL, the temporal variability in the measured aerosol size distributions was usually much larger. The elevated aerosol layers showed size distributions with very similar shapes to the size distribution in the BL, but the typical number concentration in each layer differed. The back trajectories suggested that most of the elevated layers had spent some time close to the surface previously, and that, since the air masses all had similar origins and therefore aerosol sources, the difference in number concentration was presumably due to the amount of dilution experienced through entrainment in each layer during transport.

Nucleation mode particles were observed in the elevated layers. Since the aerosol concentrations in one of the elevated layers remained constant for several days with essentially no mixing observed, this suggests the potential for new particle formation occurring in the elevated layer at the same time as in the BL. In addition, a thin "interface" layer was observed, between two distinct elevated layers, containing high concentrations of particles between 300 and $500 \mathrm{~nm}$. Without chemical composition information, not available on these flights, it was not possible to determine whether this thin layer was a result of small-scale mixing between two adjacent layers or 
whether these particles were the result of large-scale transport of smoke or dust.

In contrast to the clear-sky case, the BL for the cloudy case did not appear to be as well mixed, even though a convective $\mathrm{BL}$, expected to promote mixing, was clearly present. This was evident in both the radiosonde profile and in the larger variability exhibited in the aerosol size distributions measured in the BL, implying that the organised convective structures present were responsible for the heterogeneity seen in the BL. In the BL, the aerosol size distribution displayed a Hoppel minimum, suggesting cloud processing of aerosol particles but with variations that were again presumably due to the specific nature of the updraughts and downdraughts resulting in BL mixing that was not fully homogeneous in the upper part of the BL. Conversely, some of the convective plumes reached sufficient altitudes in the afternoon to provide a degree of mixing in the lower elevated layer, but this mixing was not spatially homogeneous.

Most of the layers diagnosed from HSRL could be identified from HYSPLIT back trajectories, although the arrival heights did not always coincide. Errors in trajectories (particularly in the vertical) arise from the difficulties that the meteorological models providing the wind fields have in accurately representing vertical motion and turbulence, the boundary layer, and other subgrid-scale features (e.g. Riddle et al., 2006; Hoffmann et al., 2016). Uncertainties in the horizontal can be determined using ensemble trajectory techniques (Stohl et al., 2001) but these are less likely to capture vertical discrepancies arising from processes that the meteorological model may not capture correctly, such as the boundary layer. A combination of HSRL and back trajectories gives much more confidence in determining the air mass origin and vertical layer extent when interpreting local measurements in terms of long-range transport.

Data availability. Atmospheric Radiation Measurement (ARM) Climate Research Facility. 2014, updated hourly. High spectral resolution lidar (HSRL). 2014-04-08 to 2014-08-22, ARM Mobile Facility (TMP) U. of Helsinki Research Station (SMEAR II), Hyytiala, Finland; AMF2 (M1). Compiled by B. Ermold, E. Eloranta, J. Garcia and J. Goldsmith. Atmospheric Radiation Measurement (ARM) Climate Research Facility Data Archive: Oak Ridge, Tennessee, USA. Data set accessed 2014-09-25 at http://dx.doi.org/ 10.5439/1025200.

Atmospheric Radiation Measurement (ARM) Climate Research Facility, 2014, updated hourly. Balloon-Borne Sounding System (SONDEWNPN). 2014-04-08 to 2014-08-22, ARM Mobile Facility (TMP) U. of Helsinki Research Station (SMEAR II), Hyytiala, Finland; AMF2 (M1). Compiled by D. Holdridge, J. Kyrouac and R. Coulter. Atmospheric Radiation Measurement (ARM) Climate Research Facility Data Archive: Oak Ridge, Tennessee, USA. Data set accessed 2014-09-25 at http://dx.doi.org/10.5439/1021460.
Author contributions. AN performed data analysis with contributions from KT and AM. RV provided data from the flight campaigns. EOC, TP, MK, and VMK contributed to the interpretation of the results. AN and EOC wrote the paper with contributions from co-authors.

Competing interests. The authors declare that they have no conflict of interest.

Acknowledgements. This work was supported by the Academy of Finland Centre of Excellence programme (project no. 307331). This project has also received funding from the European Union's Horizon 2020 research and innovation programme under grant agreement no. 689443 via project iCUPE (Integrative and Comprehensive Understanding on Polar Environments). HSRL and radiosonde data were obtained from the Atmospheric Radiation Measurement (ARM) Climate Research Facility, a US Department of Energy Office of Science user facility sponsored by the Office of Biological and Environmental Research. We are very grateful for the collaboration with ARM during the BAECC campaign in Hyytiälä, Finland. We also acknowledge the NOAA Air Resources Laboratory (ARL) for the provision of the HYSPLIT transport and dispersion model used in this publication.

Edited by: Paul Zieger

Reviewed by: four anonymous referees

\section{References}

Andreae, M., Artaxo, P., Fischer, H., Freitas, S., Grégoire, J. M. Hansel, A., Hoor, P., Kormann, R., Krejci, R., and Lange, L.: Transport of biomass burning smoke to the upper troposphere by deep convection in the equatorial region, Geophys. Res. Lett., 28, 951-954, 2001.

Apte, J. S., Marshall, J. D., Cohen, A. J., and Brauer, M.: Addressing Global Mortality from Ambient $\mathrm{PM}_{2.5}$, Environ. Sci. Technol., 49, 8057, https://doi.org/10.1021/acs.est.5b01236, 2015.

Baars, H., Kanitz, T., Engelmann, R., Althausen, D., Heese, B., Komppula, M., Preißler, J., Tesche, M., Ansmann, A., Wandinger, U., Lim, J.-H., Ahn, J. Y., Stachlewska, I. S., Amiridis, V., Marinou, E., Seifert, P., Hofer, J., Skupin, A., Schneider, F., Bohlmann, S., Foth, A., Bley, S., Pfüller, A., Giannakaki, E., Lihavainen, H., Viisanen, Y., Hooda, R. K., Pereira, S. N., Bortoli, D., Wagner, F., Mattis, I., Janicka, L., Markowicz, K. M., Achtert, P., Artaxo, P., Pauliquevis, T., Souza, R. A. F., Sharma, V. P., van Zyl, P. G., Beukes, J. P., Sun, J., Rohwer, E. G., Deng, R., Mamouri, R.-E., and Zamorano, F.: An overview of the first decade of PollyNET: an emerging network of automated Raman-polarization lidars for continuous aerosol profiling, Atmos. Chem. Phys., 16, 5111-5137, https://doi.org/10.5194/acp16-5111-2016, 2016.

Berg, L. K., Fast, J. D., Barnard, J. C., Burton, S. P., Cairns, B., Chand, D., Comstock, J. M., Dunagan, S., Ferrare, R. A., Flynn, C. J., and Hair, J. W.: The Two-Column Aerosol Project: Phase I - Overview and impact of elevated aerosol layers on 
aerosol optical depth, J. Geophys. Res.-Atmos., 121, 336-361, https://doi.org/10.1002/2015JD023848, 2016.

Berland, K., Rose, C., Pey, J., Culot, A., Freney, E., Kalivitis, N., Kouvarakis, G., Cerro, J. C., Mallet, M., Sartelet, K., Beckmann, M., Bourriane, T., Roberts, G., Marchand, N., Mihalopoulos, N., and Sellegri, K.: Spatial extent of new particle formation events over the Mediterranean Basin from multiple ground-based and airborne measurements, Atmos. Chem. Phys., 17, 9567-9583, https://doi.org/10.5194/acp-17-9567-2017, 2017.

Boy, M., Petäjä, T., Maso, M. D., Rannik, Ü., Rinne, J., Aalto, P., Laaksonen, A., Vaattovaara, P., Joutsensaari, J., Hoffmann, T., and Warnke, J.: Overview of the field measurement campaign in Hyytiälä, August 2001 in the framework of the EU project OSOA, Atmos. Chem. Phys., 4, 657-678, https://doi.org/10.5194/acp-4-657-2004, 2004

Burton, S. P., Ferrare, R. A., Hostetler, C. A., Hair, J. W., Rogers, R. R., Obland, M. D., Butler, C. F., Cook, A. L., Harper, D. B., and Froyd, K. D.: Aerosol classification using airborne High Spectral Resolution Lidar measurements - methodology and examples, Atmos. Meas. Tech., 5, 73-98, https://doi.org/10.5194/amt-5-732012, 2012.

Clarke, A. D. and Kapustin, V. N.: A Pacific aerosol survey. Part 1: A decade of data on particle production, transport, evolution, and mixing in the troposphere, J. Atmos. Sci., 59, 363-382, 2002.

Clarke, A. D., Collins, W. G., Rasch, P. J., Kapustin, V. N., Moore, K., Howell, S., and Fuelberg, H. E.: Dust and pollution transport on global scales: Aerosol measurements and model predictions, J. Geophys. Res., 106, 32555-32569, https://doi.org/10.1029/2000JD900842, 2001.

Collins, D. R., Flagan, R. C., and Seinfeld, J. H.: Improved inversion of scanning DMA data, Aerosol. Sci. Technol., 36, 1-9, 2002.

Crumeyrolle, S., Manninen, H. E., Sellegri, K., Roberts, G., Gomes, L., Kulmala, M., Weigel, R., Laj, P., and Schwarzenboeck, A.: New particle formation events measured on board the ATR-42 aircraft during the EUCAARI campaign, Atmos. Chem. Phys., 10, 6721-6735, https://doi.org/10.5194/acp-106721-2010, 2010.

Dal Maso, M., Kulmala, M., Riipinen, I., Wagner, R., Hussein, T., Aalto, P. P., and Lehtinen, K. E.: Formation and growth of fresh atmospheric aerosols: eight years of aerosol size distribution data from SMEAR II, Hyytiala, Finland, Boreal Environ. Res., 10, 323-336, 2005.

Donnell, E. A., Fish, D. J., Dicks, E. M., and Thorpe, A. J.: Mechanisms for pollutant transport between the boundary layer and the free troposphere, J. Geophys. Res., 106, 7847-7856, https://doi.org/10.1029/2000JD900730, 2001.

Dunne, E. M., Gordon, H., Kürten, A., Almeida, J., Duplissy, J., Williamson, C., Barmet, P., Benduhn, F., Bianchi, F., Breitenlechner, M., Clarke, A., Curtius, J., Dommen, J., Donahue, N. M., Ehrhart, S., Flagan, R. C., Franchin, A., Guida, R., Hakala, J., Hansel, A., Heinritzi, M., Jokinen, T., Kangasluoma, J., Kirkby, J., Kulmala, M., Kupc, A., Lawler, M. J., Lehtipalo, K., Makhmutov, V., Mann, G., Mathot, S., Merikanto, J., Miettinen, P., Nenes, A., Onnela, A., Rap, A., Reddington, C. L. S., Riccobono, F., Richards, N. A. D., Rissanen, M. P., Rondo, L., Sarnela, N., Schobesberger, S., Sengupta, K., Simon, M., Sipilä, M., Smith, J. N., Stozkhov, Y., Tomé, A., Tröstl, J., Wagner, P. E., Wimmer, D., Winkler, P. M., Worsnop, D. R., and Carslaw, K. S: Global particle formation from CERN CLOUD measurements, Science, 354, 1119-1124, https://doi.org/10.1126/science.aaf2649, 2016.

Eloranta, E.: High Spectral Resolution Lidar, In Lidar, 143-163, Springer-Verlag, New York, 2005.

Eloranta, E. W. and Razenkov, I. A.: Frequency locking to the center of a $532 \mathrm{~nm}$ iodine absorption line by using stimulated Brillouin scattering from a single-mode fiber, Opt. Lett., 31, 234 237, 2006.

Ermold, B., Eloranta, E., Garcia, J., and Goldsmith, J.: Atmospheric Radiation Measurement (ARM), data set available at: https://doi.org/10.5439/1025200, last access: 25 September 2014.

Fast, J. D., Berg, L. K., Zhang, K., Easter, R. C., Ferrare, R. A., Hair, J. W., Hostetler, C. A., Liu, Y., Ortega, I., Sedlacek, A., and Shilling, J. E.: Model representations of aerosol layers transported from North America over the Atlantic Ocean during the Two-Column Aerosol Project, J. Geophys. Res.-Atmos., 121, 9814-9848, https://doi.org/10.1002/2016JD025248, 2016.

Glassmeier, F., Possner, A., Vogel, B., Vogel, H., and Lohmann, U.: A comparison of two chemistry and aerosol schemes on the regional scale and the resulting impact on radiative properties and liquid- and ice-phase aerosol-cloud interactions, Atmos. Chem. Phys., 17, 8651-8680, https://doi.org/10.5194/acp17-8651-2017, 2017.

Goldsmith, J.: High Spectral Resolution Lidar (HSRL) Instrument Handbook, No. DOE/SC-ARM-TR-157, DOE Office of Science Atmospheric Radiation Measurement (ARM) Program (United States), 2016.

Groß, S., Tesche, M., Freudenthaler, V., Toledano, C., Wiegner, M., Ansmann, A., Althausen, D., and Seefeldner, M.: Characterization of Saharan dust, marine aerosols and mixtures of biomassburning aerosols and dust by means of multi-wavelength depolarization and Raman lidar measurements during SAMUM 2. Tellus B, 63, 706-724, https://doi.org/10.1111/j.16000889.2011.00556.x, 2011.

Grund, C. J. and Eloranta, E. W.: University of Wisconsin high spectral resolution lidar, Opt. Eng., 30, 6-12, 1991.

Hari, P. and Kulmala, M.: Station for Measuring EcosystemAtmosphere relations (SMEAR II), Boreal Environ. Res., 10, 315-322, 2005.

Haywood, J. and Boucher, O.: Estimates of the direct and indirect radiative forcing due to tropospheric aerosols: A review, Rev. Geophys., 38, 513-543, https://doi.org/10.1029/1999RG000078, 2000.

Haywood, J. M. and Ramaswamy, V.: Global sensitivity studies of the direct radiative forcing due to anthropogenic sulfate and black carbon aerosols, J. Geophys. Res.-Atmos., 103, 60436058, https://doi.org/10.1029/97JD03426, 1998.

Hoffmann, L., Rößler, T., Griessbach, S., Heng, Y., and Stein, O.: Lagrangian transport simulations of volcanic sulfur dioxide emissions: Impact of meteorological data products, J. Geophys. Res.: Atmos., 121, 4651-4673, 2016.

Holdridge, D., Kyrouac, J., and Coulter, R.: Atmospheric Radiation Measurement (ARM), data set available at: https://doi.org/10.5439/1021460, last access: 25 September 2014.

Holtslag, A. A., Svensson, G., Baas, P., Basu, S., Beare, B., Beljaars, A. C., Bosveld, F. C., Cuxart, J., Lindvall, J., Steeneveld, G. J., Tjernström, M., and Van De Wiel, B. J.: Stable Atmo- 
spheric Boundary Layers and Diurnal Cycles: Challenges for Weather and Climate Models, B. Am. Meteor. Soc., 94, 16911706, https://doi.org/10.1175/BAMS-D-11-00187.1, 2013.

Intergovernmental Panel on Climate Change (IPCC), edited by: Stocker, T. F., Qin, D., Plattner, G. K., Tignor, M., Allen, S. K., Boschung, J., Nauels, A., Xia, Y., Bex, V., and Midgley, P. M., Cambridge University Press, Cambridge, UK and New York, NY, USA, 1535 pp., 2013.

Kaufman, Y., Tanré, D., and Boucher, O.: A satellite view of aerosols in the climate system, Nature, 419, 215-223, https://doi.org/10.1038/nature01091, 2002.

Kulmala, M., Vehkamäki, H., Petäjä, T., Dal Maso, M., Lauri, A., Kerminen, V., Birmili, W., and McMurry, P.: Formation and growth rates of ultrafine atmospheric particles: a review of observations, J. Aerosol Sci., 35, 143-176, 2004.

Kulmala, M., Riipinen, I., Sipilä, M., Manninen, H., Petäjä, Junninen, H., Dal Maso, M., Mordas, G., Mirme, A., Vana, M., Hirsikko, A., Laakso, L., Harrison, R., Hanson, I., Leung, C., Lehtinen, K., and Kerminen, V.-M.: Toward direct measurement of atmospheric nucleation, Science, 318, 89-92, 2007.

Kulmala, M., Kontkanen, J., Junninen, H., Lehtipalo, K., Manninen, H., Nieminen, T., Petaja, T., Sipila, M., Schobesberger, S., Rantala, P., Franchin, A., Jokinen, T., Jarvinen, E., Aijala, M., Kangasluoma, J., Hakala, J., Aalto, P., Paasonen, P., Mikkila, J., Vanhanen, J., Aalto, J., Hakola, H., Makkonen, U., Ruuskanen, T., Mauldin, R., Duplissy, J., Vehkamaki, H., Back, J., Kortelainen, A., Riipinen, I., Kurten, T., Johnston, M., Smith, J., Ehn, M., Mentel, T., Lehtinen, K., Laaksonen, A., Kerminen, V., and Worsnop, D.: Direct observations of atmospheric aerosol nucleation, Science, 339, 943-946, 2013.

Laakso, L., Petäjä, T., Lehtinen, K. E. J., Kulmala, M., Paatero, J., Horrak, U., Tammet, H., and Joutsensaari, J.: Ion production rate in a boreal forest based on ion, particle and radiation measurements, Atmos. Chem. Phys., 4, 1933-1943, https://doi.org/10.5194/acp-4-1933-2004, 2004.

Lacagnina, C., Hasekamp, O. P., and Torres, O.: Direct radiative effect of aerosols based on PARASOL and OMI satellite observations, J. Geophys. Res.-Atmos., 122, 2366-2388, https://doi.org/10.1002/2016JD025706, 2017.

McCormick, R. A. and Ludwig, J. H.: Climate modification by atmospheric aerosols, Science, 156, 1358-1359, 1967.

McNaughton, C. S., Clarke, A. D., Howell, S. G., Pinkerton, M., Anderson, B., Thornhill, L., Hudgins, C., Winstead, E., Dibb, J. E., and Scheuer, E.: Results from the DC-8 Inlet Characterization Experiment (DICE): Airborne versus surface sampling of mineral dust and sea salt aerosols, Aerosol Sci. Technol., 41, 136159, 2007.

Morille, Y., Haeffelin, M., Drobinski, P., and Pelon, J.: STRAT: An automated algorithm to retrieve the vertical structure of the atmosphere from single-channel lidar data, J. Atmos. Ocean. Tech., 24, 761-775, 2007.

Myhre, G., Samset, B. H., Schulz, M., Balkanski, Y., Bauer, S., Berntsen, T. K., Bian, H., Bellouin, N., Chin, M., Diehl, T., and Easter, R. C.: Radiative forcing of the direct aerosol effect from AeroCom Phase II simulations, Atmos. Chem. Phys., 13, 18531877, https://doi.org/10.5194/acp-13-1853-2013, 2013.

Müller, D., Hostetler, C. A., Ferrare, R. A., Burton, S. P., Chemyakin, E., Kolgotin, A., Hair, J. W., Cook, A. L., Harper, D. B., Rogers, R. R., Hare, R. W., Cleckner, C. S., Obland, M.
D., Tomlinson, J., Berg, L. K., and Schmid, B.: Airborne Multiwavelength High Spectral Resolution Lidar (HSRL-2) observations during TCAP 2012: vertical profiles of optical and microphysical properties of a smoke/urban haze plume over the northeastern coast of the US, Atmos. Meas. Tech., 7, 3487-3496, https://doi.org/10.5194/amt-7-3487-2014, 2014.

O’Dowd, C., Yoon, Y., Junkermann, W., Aalto, P., Kulmala, M., Lihavainen, H., and Viisanen, Y.: Airborne measurements of nucleation mode particles II: boreal forest nucleation events, Atmos. Chem. Phys., 9, 937-944, https://doi.org/10.5194/acp-9937-2009, 2009.

O’Neill, N. T., Pancrati, O., Baibakov, K., Eloranta, E., Batchelor, R. L., Freemantle, J., McArthur, L. J. B., Strong, K., and Lindenmaier, R.: Occurrence of weak, sub-micron, tropospheric aerosol events at high Arctic latitudes, Geophys. Res. Lett., 35, L14814, https://doi.org/10.1029/2008GL033733, 2008.

Pappalardo, G., Amodeo, A., Apituley, A., Comeron, A., Freudenthaler, V., Linné, H., Ansmann, A., Bösenberg, J., D’Amico, G., Mattis, I., Mona, L., Wandinger, U., Amiridis, V., AladosArboledas, L., Nicolae, D., and Wiegner, M.: EARLINET: towards an advanced sustainable European aerosol lidar network, Atmos. Meas. Tech., 7, 2389-2409, https://doi.org/10.5194/amt7-2389-2014, 2014.

Petäjä, T., O’Connor, E. J., Moisseev, D., Sinclair, V. A., Manninen, A. J., Väänänen, von Lerber, A., Thornton, J. A., Nicoll, K., Petersen, W., Chandrasekar, V., Smith, J. N., Winkler, P. M., Krüger, O., Hakola, H., Timonen, H., Brus, D., Laurila, T., Asmi, E., Riekkola, M.-L., Mona, L., Massoli, P., Engelmann, R., Komppula, M., Wang, J., Kuang, C., Bäck, J., Virtanen, A., Levula, J., Ritsche, M., and Hickmon, N.: BAECC: A field campaign to elucidate the impact of biogenic aerosols on clouds and climate, B. Am. Meteorol. Soc., 97, 1909-1928, 2016.

Pope III, C. A., Cropper, M., Coggins, J., and Cohen, A.: Health benefits of air pollution abatement policy: role of the shape of the concentration-response function, J. Air Waste Manage. Assoc., 65, 516-522, 2015.

Reid, J. S., Kuehn, R. E., Holz, R. E., Eloranta, E. W., Kaku, K. C., Kuang, S., Newchurch, M. J., Thompson, A. M., Trepte, C. R., Zhang, J. and Atwood, S. A., Hand, J. L., Holben, B. N., Minnis, P., and Posselt, D. J.: Ground-based High Spectral Resolution Lidar observation of aerosol vertical distribution in the summertime Southeast United States, J. Geophys. Res.-Atmos., 122, 2970-3004, https://doi.org/10.1002/2016JD025798, 2017.

Riddle, E. E., Voss, P. B., Stohl, A., Holcomb, D., Maczka, D., Washburn, K., and Talbot, R. W.: Trajectory model validation using newly developed altitude-controlled balloons during the International Consortium for Atmospheric Research on Transport and Transformations 2004 campaign, J. Geophys.. Res., 111, D23S57, https://doi.org/10.1029/2006JD007456, 2006.

Saponaro, G., Kolmonen, P., Sogacheva, L., Rodriguez, E., Virtanen, T., and de Leeuw, G.: Estimates of the aerosol indirect effect over the Baltic Sea region derived from 12 years of MODIS observations, Atmos. Chem. Phys., 17, 3133-3143, https://doi.org/10.5194/acp-17-3133-2017, 2017.

Sawamura, P., Moore, R. H., Burton, S. P., Chemyakin, E., Müller, D., Kolgotin, A., Ferrare, R. A., Hostetler, C. A., Ziemba, L. D., Beyersdorf, A. J., and Anderson, B. E.: HSRL-2 aerosol optical measurements and microphysical retrievals vs. airborne in situ measurements during DISCOVER-AQ 2013: an in- 
tercomparison study, Atmos. Chem. Phys., 17, 7229-7243, https://doi.org/10.5194/acp-17-7229-2017, 2017.

Schobesberger, S., Väänänen, R., Leino, K., Virkkula, A., Backman, J., Pohja, T., Siivola, E., Franchin, A., Mikkilä, J., and Paramonov, M.: Airborne measurements over the boreal forest of southern Finland during new particle formation events in 2009 and 2010, Boreal Environ. Res., 18, 145-163, 2013.

She, C. Y., Alvarez, R. J., Caldwell, L. M., and Krueger, D. A.: High-spectral-resolution Rayleigh-Mie lidar measurement of aerosol and atmospheric profiles, Opt. Lett., 17, 541-543, https://doi.org/10.1364/OL.17.000541, 1992.

Shipley, S. T., Tracy, D. H., Eloranta, E. W., Trauger, J. T., Sroga, J. T., Roesler, F. L., and Weinman, J. A.: High spectral resolution lidar to measure optical scattering properties of atmospheric aerosols. 1: Theory and instrumentation, Appl. Opt., 22, 37163724, https://doi.org/10.1364/AO.22.003716, 1983.

Sinclair, V. A., Gray, S. L., and Belcher, S. E.: Controls on boundary layer ventilation: Boundary layer processes and large-scale dynamics, J. Geophys. Res., 115, D11107, https://doi.org/10.1029/2009JD012169, 2010.

Stein, A. F., Draxler, R. R, Rolph, G. D., Stunder, B. J. B., Cohen, M. D., and Ngan, F.: NOAA's HYSPLIT atmospheric transport and dispersion modeling system, B. Am. Meteor. Soc., 96, 20592077, https://doi.org/10.1175/BAMS-D-14-00110.1, 2015.

Stohl, A., Haimberger, L., Scheele, M. P., and Wernli, H.: An intercomparison of results from three trajectory models, Meteorol. Appl., 8, 127-135, 2001.

Stull, R. B.: An introduction to boundary layer meteorology, Springer Science \& Business Media, 2012.

Sundström, A.-M., Arola, A., Kolmonen, P., Xue, Y., de Leeuw, G., and Kulmala, M.: On the use of a satellite remote-sensingbased approach for determining aerosol direct radiative effect over land: a case study over China, Atmos. Chem. Phys., 15, 505-518, https://doi.org/10.5194/acp-15-505-2015, 2015.

Ten Hoeve, J. E. and Augustine, J. A.: Aerosol effects on cloud cover as evidenced by ground-based and space-based observations at five rural sites in the United States, Geophys. Res. Lett., 43, 793-801, https://doi.org/10.1002/2015GL066873, 2016.

Tie, X., Wu, D., and Brasseur, G.: Lung cancer mortality and exposure to atmospheric aerosol particles in Guangzhou, China, Atmos. Environ., 43, 2375-2377, https://doi.org/10.1016/j.atmosenv.2009.01.036, 2009.
Tunved, P., Hansson, H. C., Kerminen, V. M., Ström, J., Dal Maso, M., Lihavainen, H., Viisanen, Y., Aalto, P. P., Komppula, M., and Kulmala, M.: High natural aerosol loading over boreal forests, Science, 312, 261-263, 2006.

Väänänen, R., Krejci, R., Manninen, H. E., Manninen, A., Lampilahti, J., Mazon, S. B., Nieminen, T., Yli-Juuti, T., Kontkanen, J., Asmi, A., and Aalto, P. P.: Vertical and horizontal variation of aerosol number size distribution in the boreal environment, Atmos. Chem. Phys. Discuss., https://doi.org/10.5194/acp-2016556, in review, 2016.

Wandinger, U., Müller, D., Böckmann, C., Althausen, D., Matthias, V., Bösenberg, J., Weiß, V., Fiebig, M., Wendisch, M., Stohl, A., and Ansmann, A.: Optical and microphysical characterization of biomass-burning and industrial-pollution aerosols frommultiwavelength lidar and aircraft measurements, J. Geophys. Res.-Atmos., 107, 8125, https://doi.org/10.1029/2000JD000202, 2002.

Wang, J., Krejci, R., Giangrande, S., Kuang, C., Barbosa, H. M., Brito, J., Carbone, S., Chi, X. G., Comstock, J., Ditas, F., Lavric, J., Manninen, H. E., Mei, F., Moran-Zuloaga, D., Pohlker, C., Pohlker, M. L., Saturno, J., Schmid, B., Souza, R. A. F., Springston, S. R., Tomlinson, J. M., Toto, T., Walter, D., Wimmer, D., Smith, J. N., Kulmala, M., Machado, L. A. T., Artaxo, P., Andreae, M. O., Petaja, T., and Martin, S. T.: Amazon boundary layer aerosol concentration sustained by vertical transport during rainfall, Nature, 539, 416-419, 2016.

Yu, H., Kaufman, Y. J., Chin, M., Feingold, G., Remer, L. A., Anderson, T. L., Balkanski, Y., Bellouin, N., Boucher, O., Christopher, S., and DeCola, P.: A review of measurement-based assessments of the aerosol direct radiative effect and forcing, Atmos. Chem. Phys., 6, 613-666, https://doi.org/10.5194/acp-6613-2006, 2006.

Zhang, S., Wang, M., Ghan, S. J., Ding, A., Wang, H., Zhang, K., Neubauer, D., Lohmann, U., Ferrachat, S., Takeamura, T., Gettelman, A., Morrison, H., Lee, Y., Shindell, D. T., Partridge, D. G., Stier, P., Kipling, Z., and Fu, C.: On the characteristics of aerosol indirect effect based on dynamic regimes in global climate models, Atmos. Chem. Phys., 16, 2765-2783, https://doi.org/10.5194/acp-16-2765-2016, 2016. 